Aquatic Plant Control Research Program

\title{
Aquatic Vegetation Restoration in El Dorado Lake, Kansas: A Case Study
}

Gary Owen Dick and R. Michael Smart

May 2004

US Army Corps of Engineers ${ }_{\circledast}$

Engineer Research and Development Center

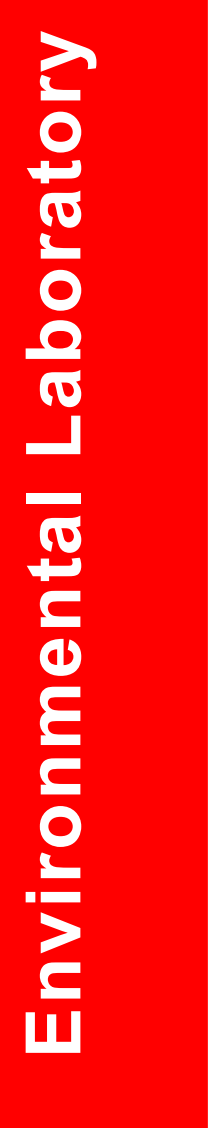




\section{Aquatic Vegetation Restoration in EI Dorado Lake, Kansas: A Case Study}

Gary Owen Dick, R. Michael Smart

Lewisville Aquatic Ecosystem Research Facility

U.S. Army Engineer Research and Development Center

201 E. Jones Street

Lewisville, TX 75057

Final report

Approved for public release; distribution is unlimited 
ABSTRACT: The overall objective of the project was to begin restoration of spawning and nursery fishery habitat for the sunfish family (largemouth bass, crappie, and bluegill) lost from flood control operations (seasonal drawdowns) in El Dorado Lake, Kansas. When initially impounded, flooded terrestrial structure provided good habitat for the sunfish fishery. As flood control operations were implemented, habitat structure (primarily flooded trees and brush) degraded, leaving the lake poorly suited for this fishery. The loss of structure also contributed to increases in turbidity, further affecting the sunfish fishery.

Specific objectives of the project were to: (a) evaluate the suitability of several emergent, floatingleaved, and submersed aquatic plant species for establishment in the lake; (b) develop and test effective methods for establishing desirable aquatic plant species; and (c) establish founder colonies of aquatic plants in several areas of the lake. In addition to providing immediate nursery habitat for juvenile fish, these founder colonies were expected to provide propagules for natural spread to other areas of the lake.

DISCLAIMER: The contents of this report are not to be used for advertising, publication, or promotional purposes. Citation of trade names does not constitute an official endorsement or approval of the use of such commercial products. All product names and trademarks cited are the property of their respective owners. The findings of this report are not to be construed as an official Department of the Army position unless so designated by other authorized documents. 


\section{Contents}

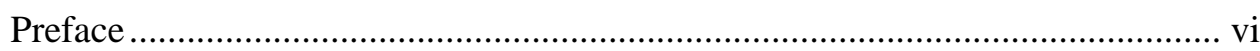

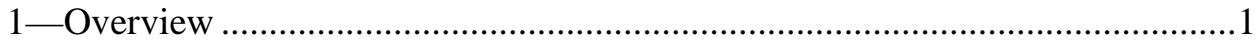

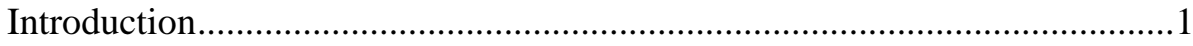

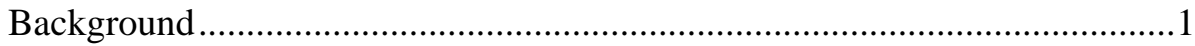

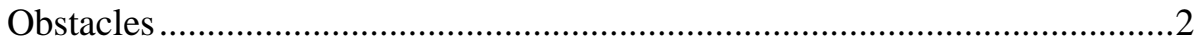

Site Selection and Large-scale Exclosure Construction .................................4

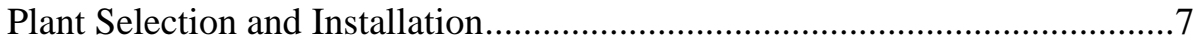

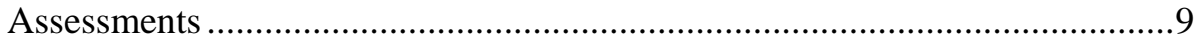

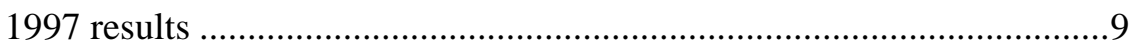

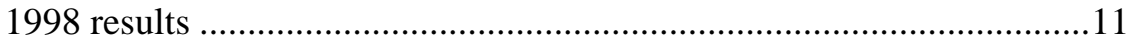

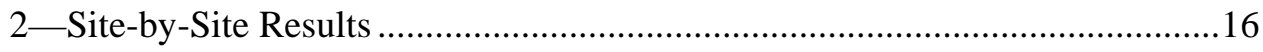

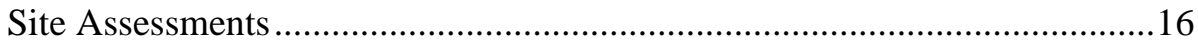

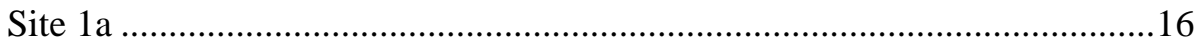

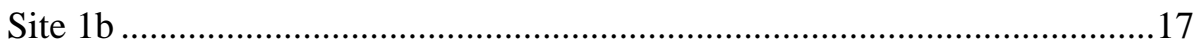

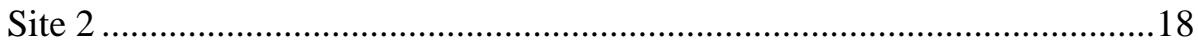

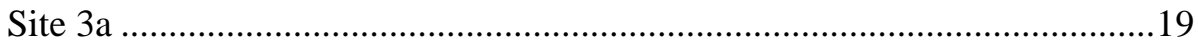

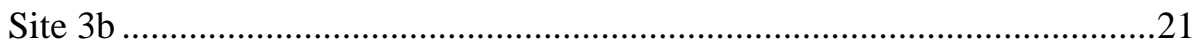

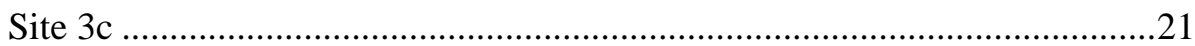

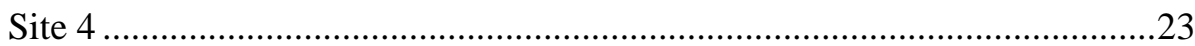

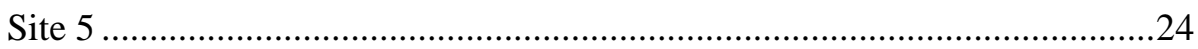

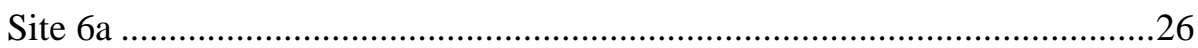

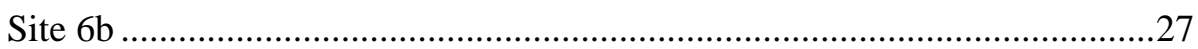

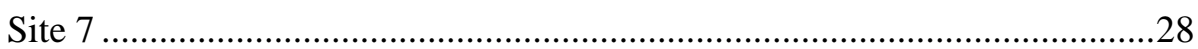

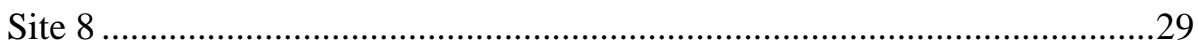

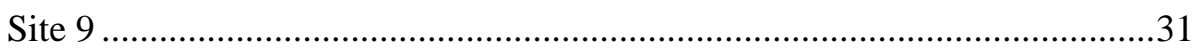

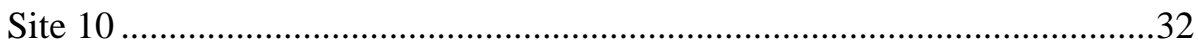

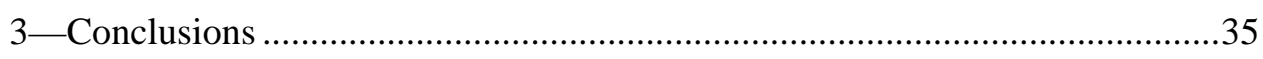

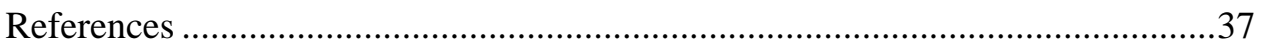

SF 298 


\section{List of Figures}

Figure 1. $\quad$ El Dorado Lake water level elevations between 1985 and

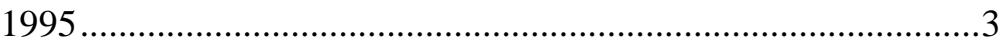

Figure 2. Ten (10) sites were selected for aquatic plant restoration around El Dorado Lake .................................................................4

Figure 3. Various protective exclosure types constructed in El

Dorado Lake..................................................................................

Figure 4. Tomato cages served as small-scale protection for individual plants in El Dorado Lake ...........................................

Figure 5. Orange cages served as small-scale protection for small sets of plants in El Dorado Lake .................................................8

Figure 6. $\quad$ GPS map of Site 1a, El Dorado Lake, October 1998 ….............18

Figure 7. GPS map of Site 2, El Dorado Lake, October 1998...................20

Figure 8. $\quad$ GPS map of Site 3a, shoreline fence in El Dorado Lake,

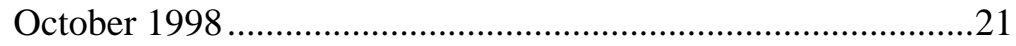

Figure 9. $\quad$ GPS map of Site 3b, El Dorado Lake, October 1998 .................22

Figure 10. GPS map of Site 3c, El Dorado Lake, October 1998 …..............23

Figure 11. GPS map of Site 4, El Dorado Lake, October 1998 …................25

Figure 12. GPS map of Site 5, El Dorado Lake, October 1998 ...................26

Figure 13. GPS map of Site 6a, El Dorado Lake, October 1998 .................28

Figure 14. GPS map of Site 6b, El Dorado Lake, October 1998..................29

Figure 15. GPS map of Site 7, El Dorado Lake, October 1998 ....................30

Figure 16. GPS map of Site 8, El Dorado Lake, October 1998 ....................31

Figure 17. GPS map of Site 9, El Dorado Lake, October 1998...................33

Figure 18. G GS map of Site 10, El Dorado Lake, October 1998..................34 


\section{List of Tables}

Table 1. $\quad$ El Dorado Lake Restoration Sites and Protective

Exclosures Constructed at Each Site During 1996.........................5

Tabbl 2. $\quad$ Aquatic Plant Species Planted in El Dorado Lake,

Kansas, in 1997 and 1998 .........................................................

Table 3. Survival of Protected and Unprotected Plants Outside of Large-scale Exclosures 3 Months after Planting in 1997 ............10

Table 4. Colony Survival at the End of the 1998-Growing Season in El Dorado Lake, Kansas.........................................................13

Table 5. Species Considered Established as Founder Colonies in El Dorado Lake after Two Growing Seasons.............................15 


\section{Preface}

The work reported herein was conducted as part of the Aquatic Plant Control Research Program (APCRP), Work Unit Number 33084. The APCRP is sponsored by Headquarters, U.S. Army Corps of Engineers (HQUSACE), and is assigned to the U.S. Army Engineer Research and Development Center (ERDC) under the purview of the Environmental Laboratory (EL), Vicksburg, MS. Funding was provided under Department of the Army Appropriation Number 96X3122, Construction General. Mr. Robert C. Gunkel, Jr., was Program Manager for the APCRP. Program Monitor during this study was Mr. Timothy R. Toplisek, HQUSACE.

Principal Investigator for this study was Dr. R. Michael Smart, Ecosystem Processes and Effects Branch, Ecology and Environmental Engineering Division (EEED), EL, ERDC, Vicksburg, MS. The report was prepared by Drs. Smart and Gary O. Dick, assigned to EEED under an Intergovernmental Personal Act Agreement with the Institute of Applied Science, University of North Texas, Denton, TX. The report was reviewed by Ms. Dian Smith, EEED, and Ms. Chetta Owens, ASI.

This investigation was performed by EL, ERDC, under the general supervision of Dr. Elizabeth Fleming, Acting Director, EL; Dr. Dave Tazik, Chief, EEED; and Dr. Al Cofrancesco, Chief and Executive Director, Aquatic Ecology and Invasive Species Branch.

COL James R. Rowan, EN, was Commander and Executive Director of ERDC. Dr. James R. Houston was Director. 


\section{Overview}

\section{Introduction}

Aquatic plants, including submersed aquatic plants, play important roles in aquatic systems. They improve water clarity and quality (James and Barko 1990) and reduce rates of shoreline erosion and sediment resuspension (James and Barko 1995). Further, aquatic plants provide valuable fish and wildlife habitat (Dibble et al. 1996) and serve as a food source for waterfowl and aquatic mammals. Native aquatic plants also help prevent spread of nuisance exotic plants (Smart et al. 1996). This role has been of primary interest to the Aquatic Plant Control Research Program (APCRP).

Because the research on aquatic plant establishment being conducted under the APCRP represented the current "state of the art" (Smart et al. 1996), the Tulsa District solicited our involvement in the planning and implementation of a Section 1135 project to establish aquatic plants for fish habitat enhancement in El Dorado Lake, Kansas. Because there is still much to learn regarding establishment of beneficial native plants, we elected to participate in this project and to incorporate some testing and data collection in an attempt to further advance the science. This report documents the restoration project and describes what we learned in the process.

\section{Background}

El Dorado Lake is located in Butler County, Kansas, near the city of El Dorado, about $56 \mathrm{~km}$ (35 miles) east of Wichita. Construction of the earthfilled dam was authorized in 1965 for flood control, water supply, water quality, and recreation and was completed in 1981. The dam impounds a section of the Walnut River, a tributary of the Arkansas River, with drainage area of $605 \mathrm{sq} \mathrm{m}$ (234 sq miles). The reservoir covers approximately 3,240 ha at an elevation of $408 \mathrm{~m}(1,339 \mathrm{ft})$ mean sea level (msl) at conservation pool, with the top of its flood control pool at elevation $411 \mathrm{~m}(1,347.5 \mathrm{ft}) \mathrm{msl}$.

A habitat restoration project was conducted in El Dorado Lake, Kansas, between 1996 and 1998. U.S. Army Engineer District (USAED), Tulsa, Kansas Department of Wildlife and Parks (KDWP), and the U.S. Army Corps of Engineers (USACE) Lewisville Aquatic Ecosystem Research Facility, Lewisville, TX, worked cooperatively to develop and implement the project, which was 75 percent funded under the authority of Section 1135(b) of the Water 
Resources Development Act of 1986, PL 99-662, as amended. In this type project, the Secretary of the Army may review civil works projects constructed by Corps of Engineers to determine need to modify structure or operation for the purpose of improving the quality of the environment in the public interest. KDWP served as the local sponsor and provided 25 percent cost-share funding, principally in the manner of in-kind labor and materials.

The overall objective of the project was to begin restoration of spawning and nursery fishery habitat for the sunfish family (largemouth bass, crappie, and bluegill) lost from flood control operations (seasonal drawdowns). When initially impounded, flooded terrestrial structure provided good habitat for the sunfish fishery. As flood control operations were implemented, habitat structure (primarily flooded trees and brush) degraded, leaving the lake poorly suited for this fishery. The loss of structure also contributed to increases in turbidity, further affecting the sunfish fishery (Ron Marteney, Fisheries Biologist, Kansas Department of Wildlife and Parks, personal communication).

The specific objectives of the project were to: (a) evaluate the suitability of several emergent, floating-leaved, and submersed aquatic plant species for establishment in the lake; (b) develop and test effective methods for establishing desirable aquatic plant species; and (c) establish founder colonies of aquatic plants in several areas of the lake. In addition to providing immediate nursery habitat for juvenile fish, these founder colonies were expected to provide propagules for natural spread to other areas of the lake (Smart and Dick 1999).

\section{Obstacles}

Establishment of aquatic vegetation was expected to meet with two major obstacles: (a) water level fluctuations; and (b) herbivory. Historically, water levels in the lake exceed conservation pool during late spring or early summer

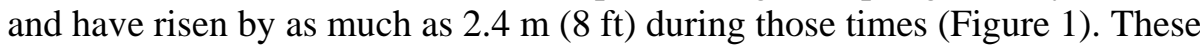
spikes have been short-lived, with floodwater release returning the lake to conservation pool within several weeks. Conversely, water levels in the lake have generally fallen below conservation pool by $1 \mathrm{~m}(3.3 \mathrm{ft})$ or less in any given year,

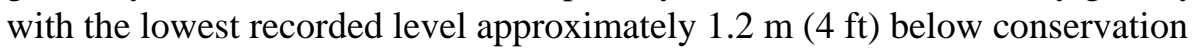
pool, during the summer of 1989. The duration of low-water conditions has been variable, with recovery dependent upon rainfall in the watershed. In addition to these fluctuations, the lake is drawn down in late winter to about 0.3 to $0.6 \mathrm{~m}$ ( 1 to $2 \mathrm{ft}$ ) below conservation pool in order to benefit waterfowl and other wildlife (Ron Marteney, personal communication).

Water levels are important to aquatic plants for several reasons. Deep water during the critical dormancy-breaking period (spring) for aquatic plants may reduce light to inhibit successful sprouting and survival of species planted too deeply relative to conservation pool. Longer periods of high water may deprive sprouted plants of light (and oxygen, in some emergent species), resulting in mortality (Barko et al. 1982). On the other hand, low-water conditions may expose plants to desiccation. While most species of aquatic plants have 


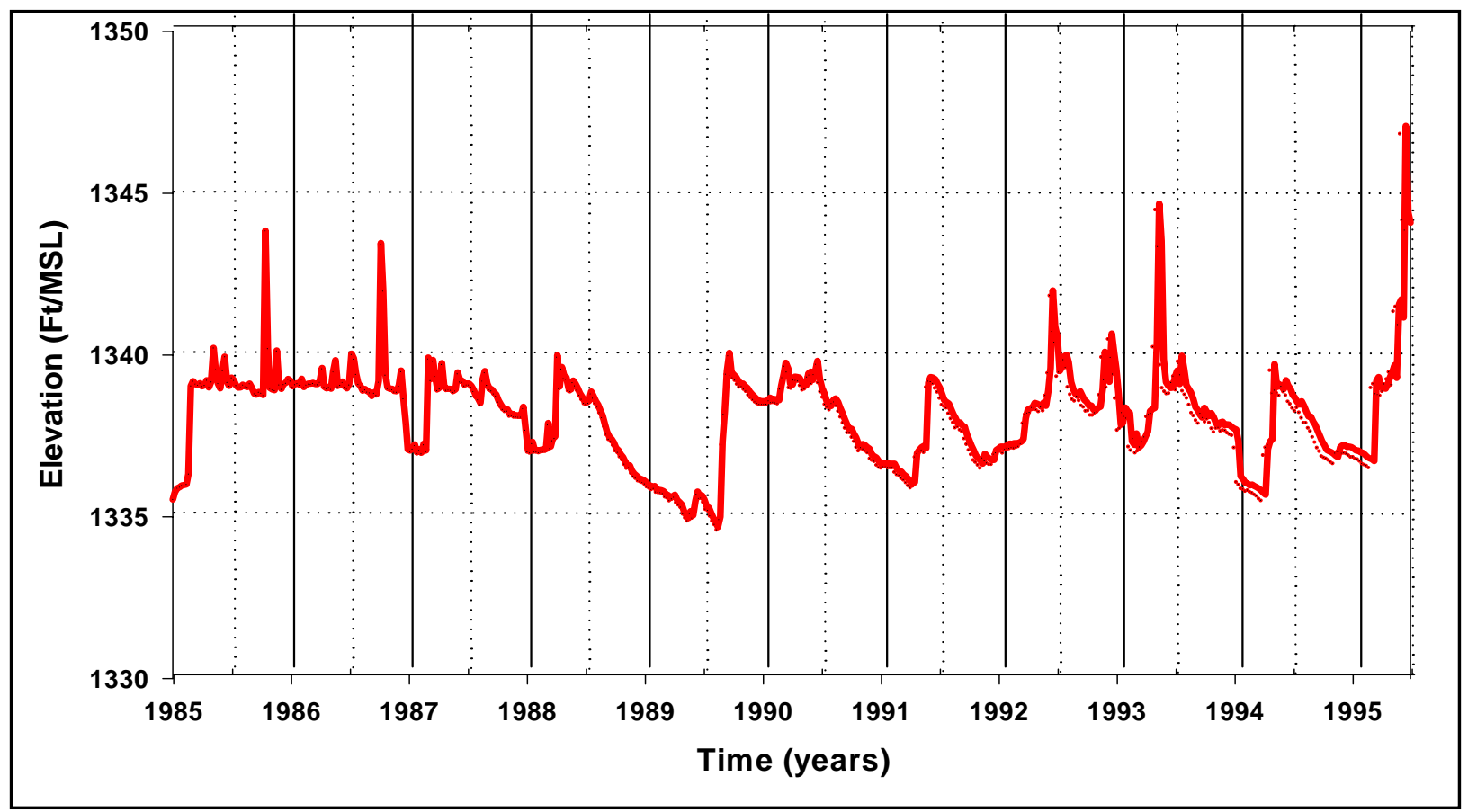

Figure 1. El Dorado Lake water level elevations between 1985 and 1995 in 7-day intervals. Conservation pool is $408-\mathrm{m}(1,339-\mathrm{ft}) \mathrm{msl}$

developed perennation strategies (such as production of desiccation-resistant seeds and tubers) to survive low-water events, newly establishing plants are highly susceptible to adverse environmental conditions and may not be able to recover from desiccation events.

Common carp (Cyprinus carpio) were known to be abundant in the lake, and semiaquatic turtles had been observed. Both of these animals are opportunistic omnivores and readily make use of aquatic plants as a food source. These have frequently been detrimental in other aquatic plant establishment projects (Dick et al. 1995; Smart et al. 1996; Doyle et al. 1997). Other animals reported from the lake, including crayfish and beavers, also damage newly installed aquatic plants in restoration projects. It was, therefore, determined that protective exclosures would be installed to prevent access to newly establishing founder colonies by these grazers. At the same time, the design of exclosures would allow spread of aquatic plants to other areas.

Other obstacles expected to potentially limit plant establishment included turbidity and excessive wave action. El Dorado Lake exhibits high turbidities from time to time, particularly following heavy rains and high wind events, when waves stir up bottom sediments along shallow flats. At these times, Secchi disk readings of less than $15 \mathrm{~cm}$ are common, especially in shallow waters (Ron Marteney, personal communication). High turbidity reduces light penetration, potentially narrowing the range of depths at which plants can successfully establish (Carter and Rybicki 1985; Nichols 1992). 
In addition to sediment resuspension and subsequent increase in turbidity, wave action produced by accompanying strong winds common to southern Kansas can shift sediments in ways that may be detrimental to newly establishing plant colonies. Sediments can be scoured out, exposing developing root systems and allowing plants to be washed away. Alternatively, sediments can be deposited at rates sufficient to smother plants (Ron Marteney, personal communication).

\section{Site Selection and Large-scale Exclosure Construction}

The lake was visited and potential planting sites were identified during summer 1995. Ten (10) sites were selected based upon depth and degree of protection from wind and waves (Figure 2). Some of these sites were divided into subsites, or sections, and most were selected on the westward, most protected side of the lake. Those selected on the less-protected east side were situated in the backs of coves.

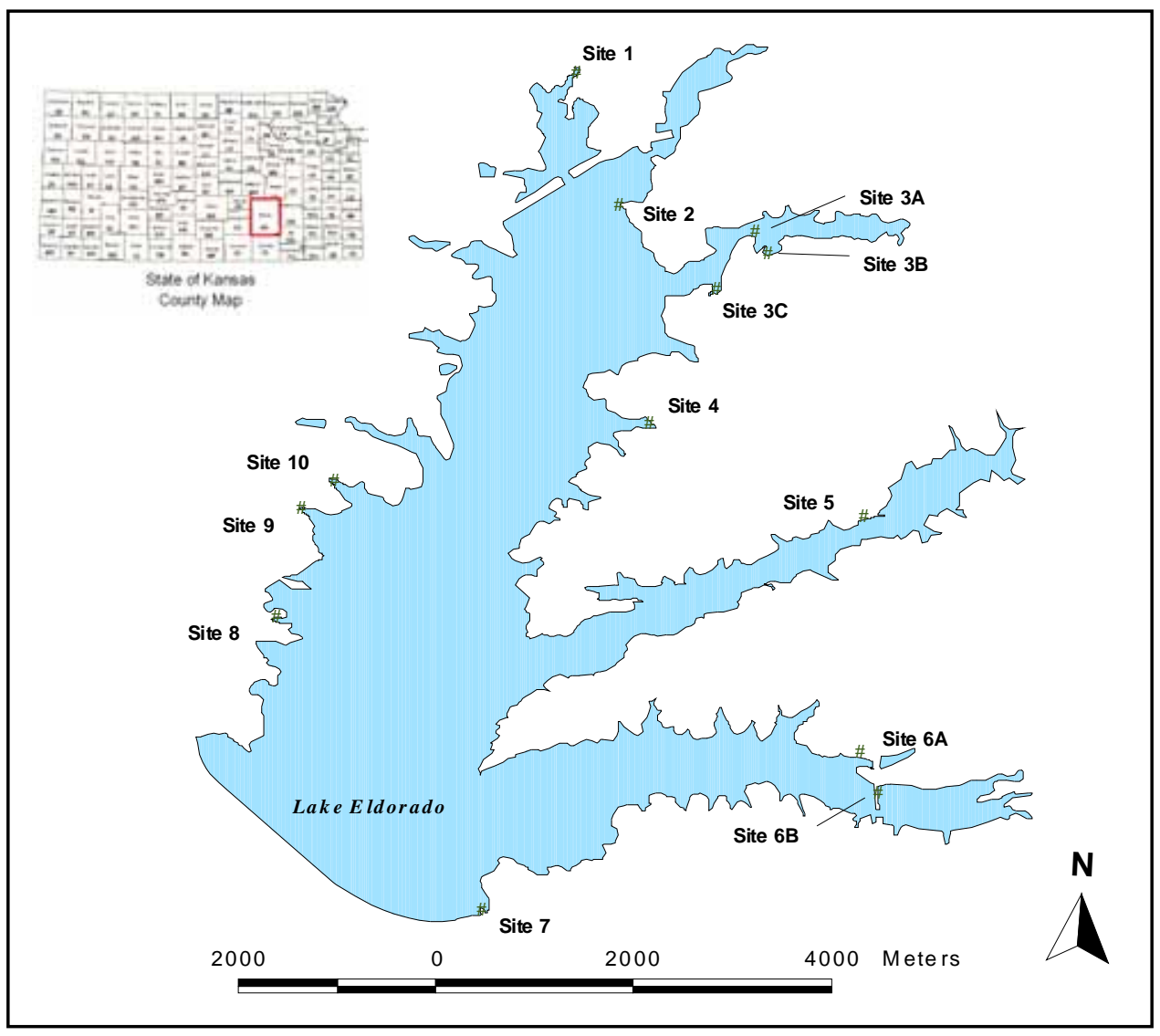

Figure 2. Ten (10) sites were selected for aquatic plant restoration around El Dorado Lake 
American water willow, Justicia americana, was the only aquatic plant species observed in the lake at this time. While widespread around the lake, it was limited to small clumps (generally $2 \mathrm{~m}$ or less in diameter), primarily along the western shoreline.

Various forms of large-scale protection were constructed at each site during the winter of 1996 (Table 1.) These types of protection were designed to protect multiple establishing plant colonies in a relatively large area $\left(50 \mathrm{~m}^{2}\right.$ and greater). To facilitate construction, the elevation of the lake was brought down to $407.5 \mathrm{~m}$ $(1,336 \mathrm{ft}) \mathrm{msl}$, about $1 \mathrm{~m}$ below conservation, during the winter drawdown period.

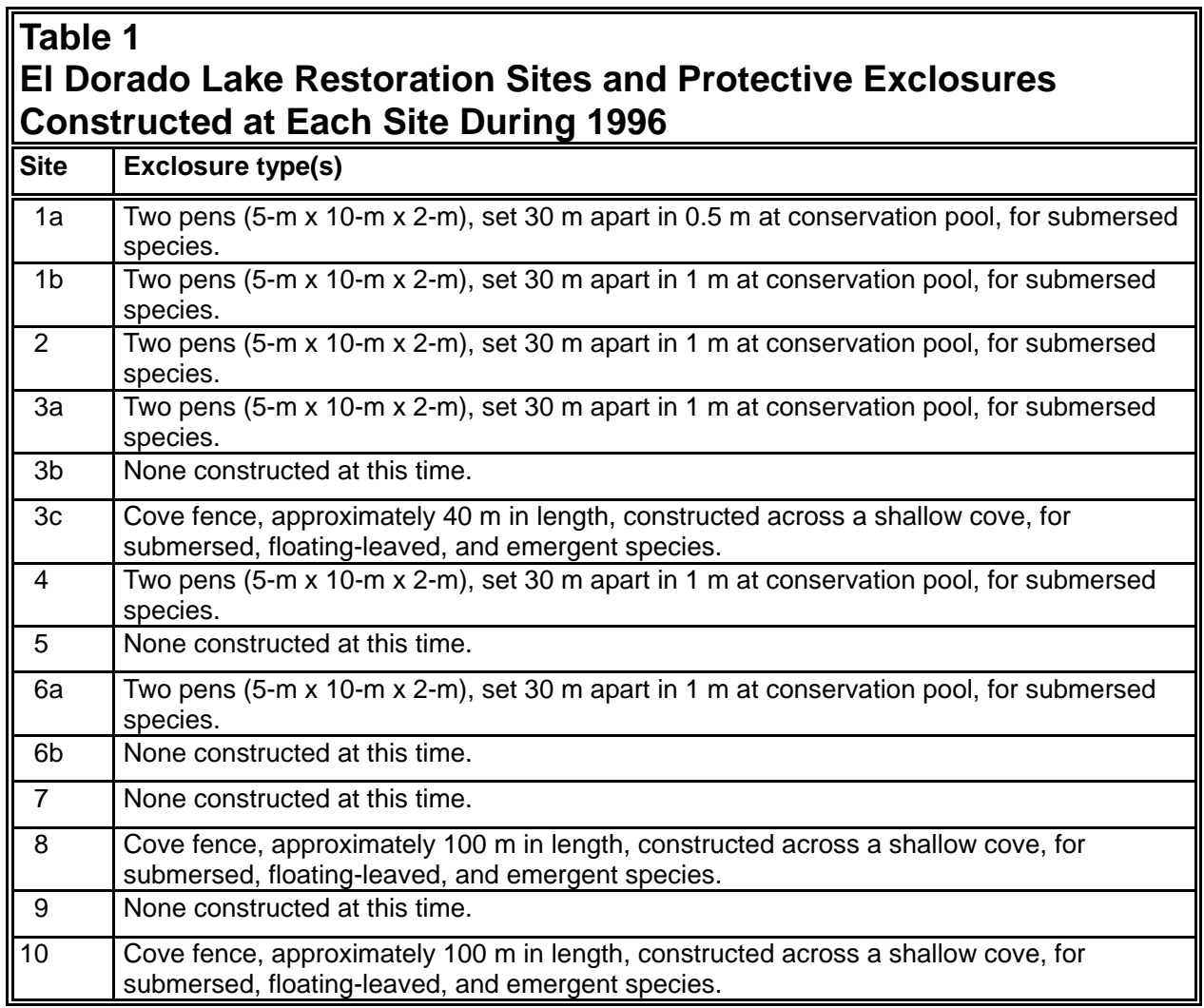

Pens were constructed in pairs at several sites in order to protect submersed aquatic plant species (Figure 3). Pens measured $5 \mathrm{~m}$ wide $\times 10 \mathrm{~m}$ long $\times 2 \mathrm{~m}$ high and were positioned parallel to one another $30 \mathrm{~m}$ apart. This positioning allowed future tie-ins to produce a single large, compartmented exclosure measuring $10 \times 40 \mathrm{~m}$. The frame of each pen consisted of T-posts set to a depth of $50 \mathrm{~cm}$ and covered with approximately 3.8-cm (1 5/8-in.) galvanized fence posts. Galvanized top rails were installed to stiffen the frame, and $5-\times 10-\mathrm{cm}$ (2- $\times 4$-in.) mesh, galvanized welded wire was attached using aluminum wire ties. A 50-cm-wide bottom flange was built into the fencing to discourage digging underneath by common carp and turtles. Pens were constructed in 0.5 - to 1 -m depths at conservation pool, leaving a minimum of $1 \mathrm{~m}$ of protective caging above the waterline at conservation pool. 


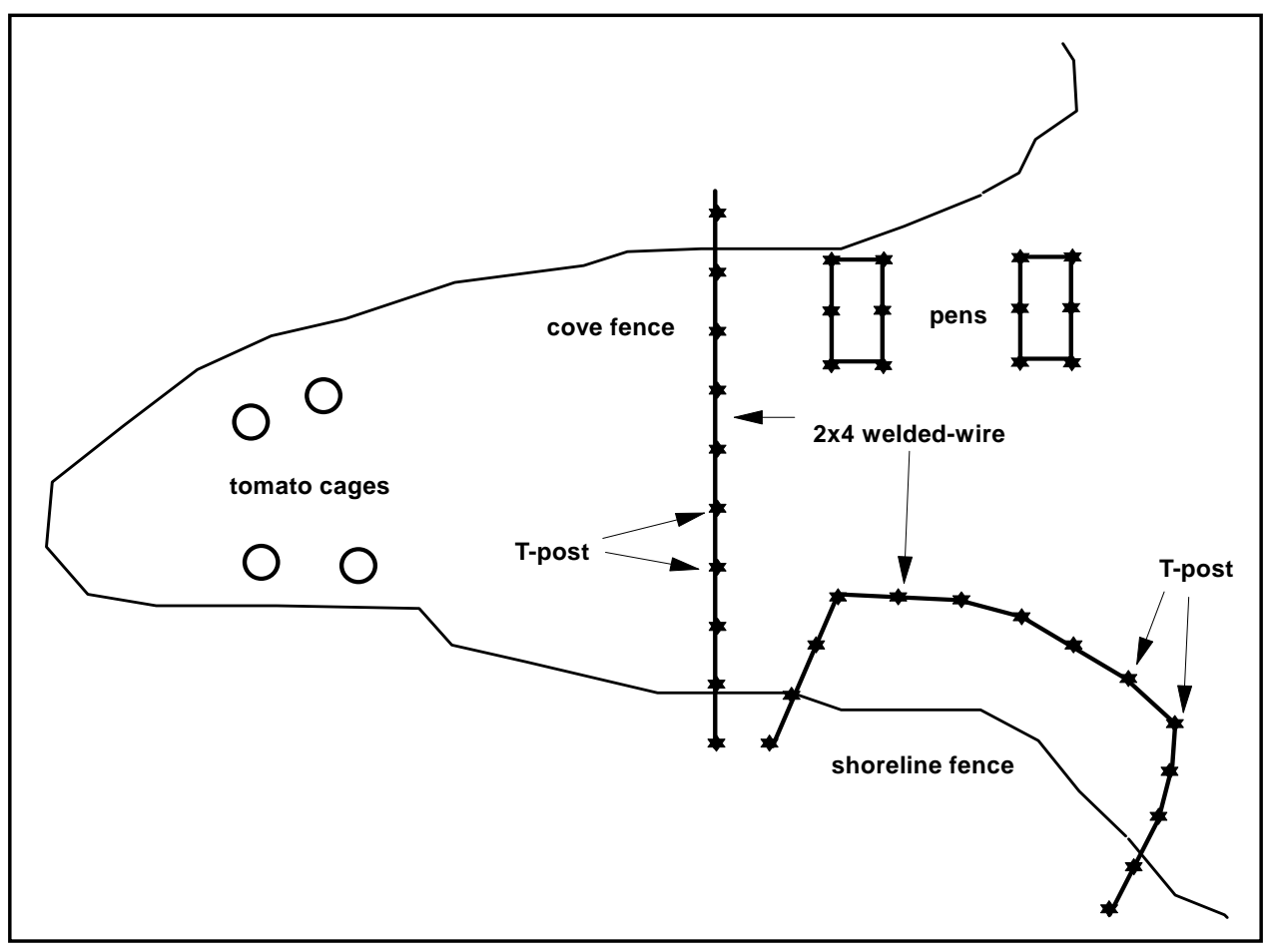

Figure 3. Various protective exclosure types constructed in El Dorado Lake

Cove fences were constructed at selected sites to protected submersed, floating-leaved, and emergent aquatic plant species (Figure 4). Each consisted of 3.8-cm (1 5/8-in.) galvanized fence posts (set over T-posts) and galvanized top rail and was constructed to rise a minimum of $0.5 \mathrm{~m}$ above conservation pool and stretched across the cove mouth, blocking access into the cove by swimming herbivores. Mesh galvanized welded wire $(5-\times 10-\mathrm{cm}(2-\times 4$-in.)) was attached to this frame.

Additional types of large-scale protection and small-scale protection were constructed and installed during planting in 1997 and 1998: shoreline fences, installed in 1998, were designed to protect submersed, floating-leaved, and emergent species, and were constructed from T-posts and 5- × 10-cm (2- by 4-in.) mesh, galvanized welded wire (Figure 4). Each shoreline fence extended from about $1 \mathrm{~m}$ above the conservation pool shoreline to depths of 1 to $1.2 \mathrm{~m}$. Fence materials were not installed on the shoreward side of these fences, which were either freestanding or built as an addition to a cove fence. This type of fence was designed to protect plants only from water-borne herbivores.

Small-scale exclosures were designed to protect individual (or a few individual) submersed, floating-leaved, or emergent plants and included tomato cages, lily cages, and orange cages. These cages were installed either inside (providing an additional level of protection in the event of exclosure damage) or outside of large-scale exclosures. Tomato cages were constructed from 5$\times 10$-cm (2- by 4-in.) mesh galvanized welded wire at heights of 1 to $1.2 \mathrm{~m}$, dependent upon planting depth and species (Figure 4). A 2-m length of welded wire was formed into an open-ended cylinder of approximately $70 \mathrm{~cm}$ in 


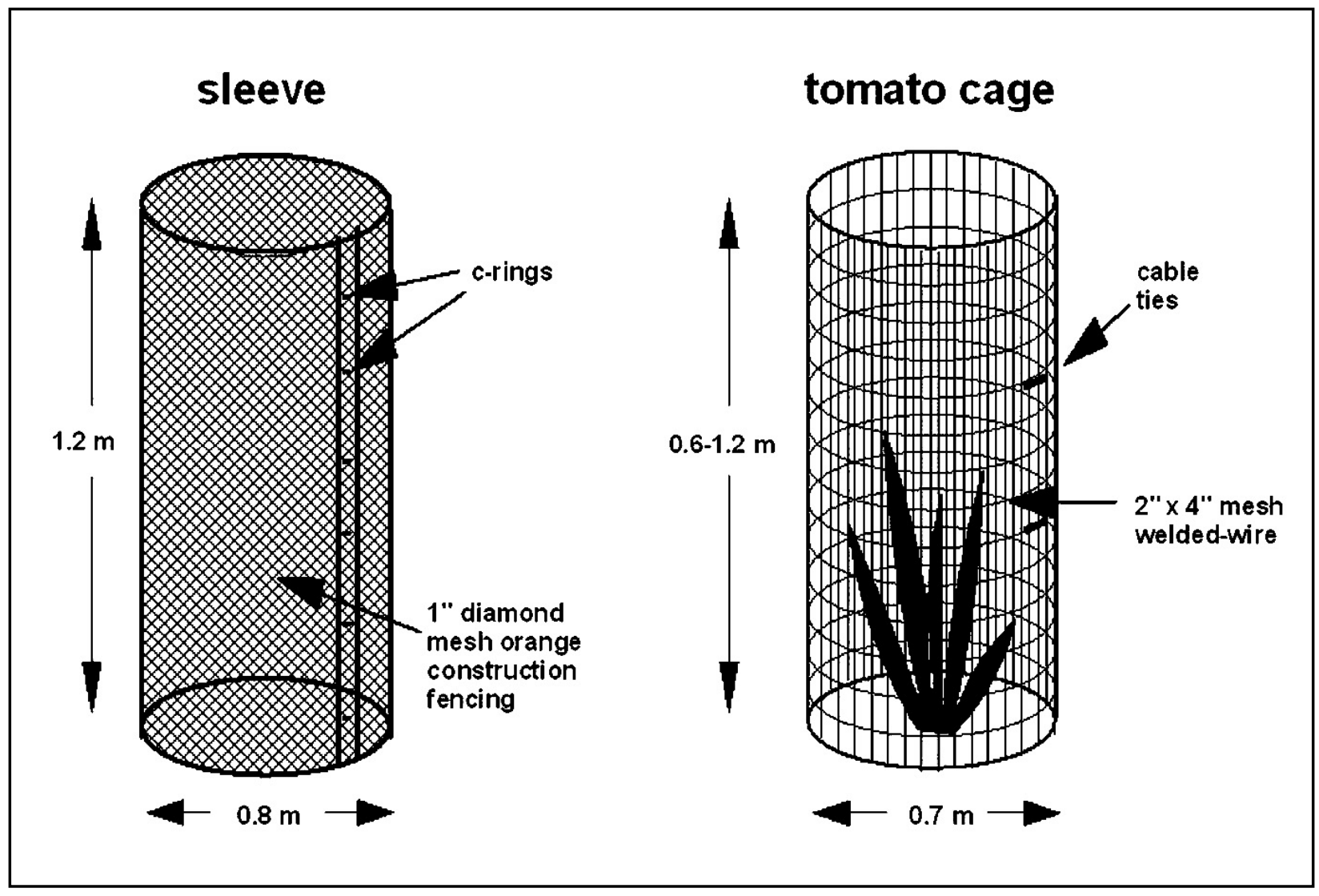

Figure 4. Tomato cages served as small-scale protection for individual plants in El Dorado Lake. Sleeves were used on some tomato cages to test protective effectiveness of a smaller mesh

diameter and anchored with pieces of rebar to protect individual plants. Lily cages were constructed in similar fashion, but greater lengths of welded wire were used to form 2- to 3-m-diam cylinders. Orange cages were constructed from plastic orange construction fencing (2-in. diamond mesh, nominal size) and rebar, and stiffened with 5-cm (2-in.) diameter (nominal size) PVC piping (Figure 5). Each plastic fence measured $2 \mathrm{~m}$ wide $\times 2 \mathrm{~m}$ long $\times 1.2 \mathrm{~m}$ high.

\section{Plant Selection and Installation}

Aquatic plant species selection was based upon several criteria: (a) all species selected were native to Kansas; (b) no species selected were considered noxious under most conditions; and (c) all species exhibited potential to tolerate water level fluctuations particular to El Dorado Lake. A list of species selected for planting in 1997 is given in Table 2.

Planting was initiated during the summer of 1997 and was completed during the summer of 1998. Initial plantings of each selected species were designed to ascertain the suitability of habitat and effectiveness of protective exclosures (of different types) for that species. Approximately 500 potted plants (10- to $15-\mathrm{cm}$ (4- to 6-in.) nominal size, nursery-grade pots) produced at the Lewisville 


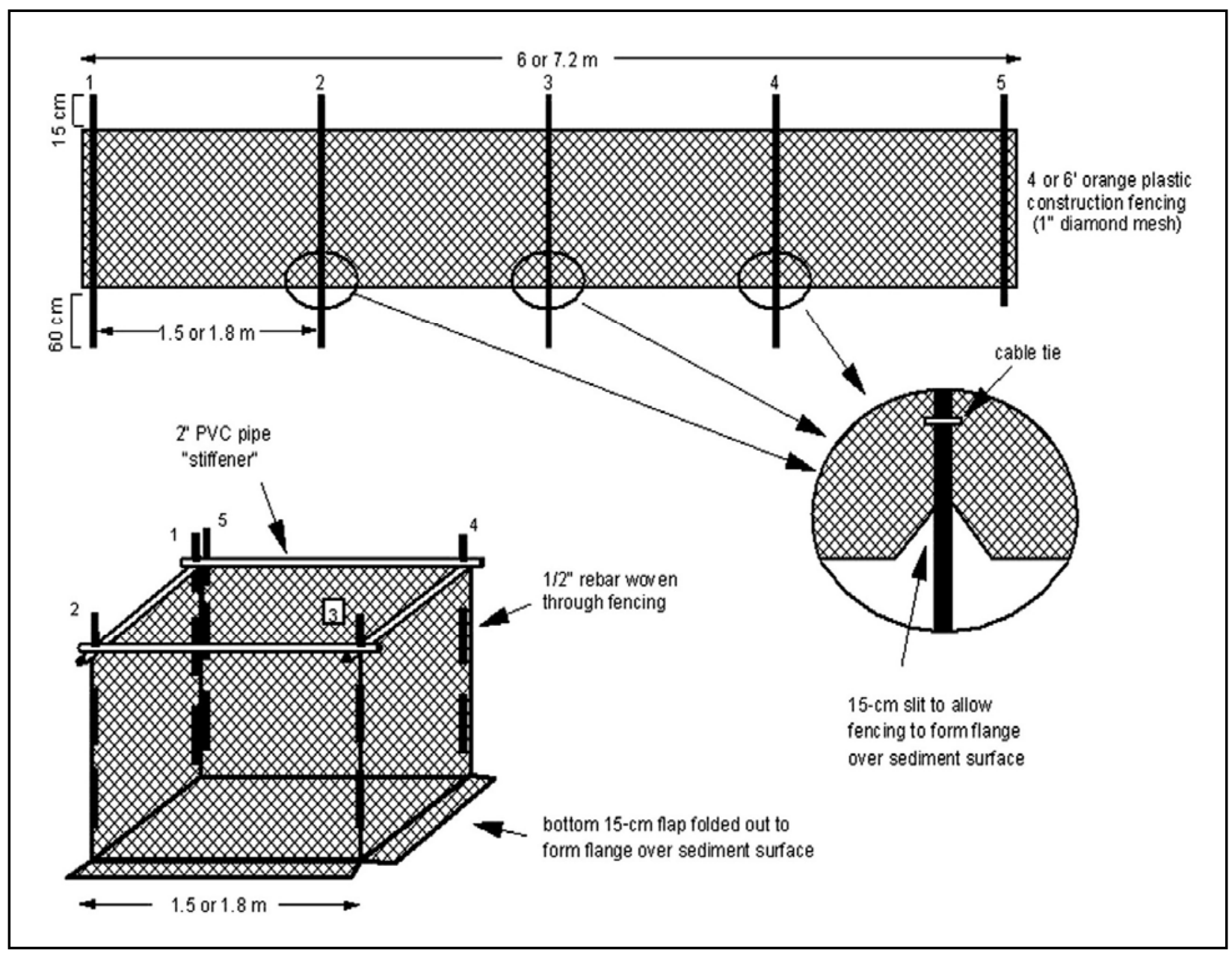

Figure 5. Orange cages served as small-scale protection for small sets of plants in El Dorado Lake

Aquatic Ecosystem Research Facility were initially planted during early summer, 1997. In addition to plants listed in Table 2, seeds and spores of southern naiad (Najas guadalupensis) and muskgrass (Chara vulgaris), both submersed forms native to Kansas, were introduced incidentally in the substrates of potted plants. For some species, different propagule types (based on availability) were planted to ascertain the most effective means of establishment for that species. In all, approximately 2,500 plants were installed in El Dorado during the course of this project.

In most cases, potted plants were individually protected with tomato cages or lily cages. Small sets of potted plants (three or four) of the same species were protected with orange cages. When a species was first planted, a test of the need for protection for that species was conducted by planting an individual of the same species outside each small-scale exclosure (this occurring both inside and outside of large-scale exclosures). 


\begin{tabular}{|c|c|c|c|c|}
\hline \multicolumn{5}{|c|}{$\begin{array}{l}\text { Table } 2 \\
\text { Aquatic Plant Species Planted in El Dorado Lake, Kansas, in } 1997 \text { and } 1998\end{array}$} \\
\hline Common Name & Species Name & Growth Form & Propagule & Year Planted \\
\hline Wild celery & Vallisneria americana & Submersed & 4-in. pot, tuber & 1997 and 1998 \\
\hline Sago pondweed & Potamogeton pectinatus & Submersed & Tuber & 1997 \\
\hline American pondweed & P. nodosus & Submersed & 4-in. pot, tuber, sprig & 1997 and 1998 \\
\hline Illinois pondweed & P. illinoensis & Submersed & 4-in. pot, sprig & 1998 \\
\hline Water stargrass & Heteranthera dubia & Submersed & 4-in. pot, sprig & 1997 and 1998 \\
\hline Elodea & Elodea canadensis & Submersed & 4-in. pot, sprig & 1997 and 1998 \\
\hline Coontail & Ceratophyllum demersum & Submersed & Sprig & 1997 \\
\hline Spatterdock & Nuphar luteum & Floating-leaved & 6-in. pot & 1997 and 1998 \\
\hline White water lily & Nymphaea odorata & Floating-leaved & 6-in. pot & 1997 and 1998 \\
\hline American lotus & Nelumbo lutea & Floating-leaved & 6-in. pot, tuber & 1997 and 1998 \\
\hline Arrowhead & Sagittaria latifolia & Emergent & 4-in. pot & 1997 and 1998 \\
\hline Bulltongue & S. graminea & Emergent & 4-in. pot & 1997 and 1998 \\
\hline Pickerelweed & Pontederia cordata & Emergent & 6-in. pot & 1998 and 1998 \\
\hline Water willow & Justicia americana & Emergent & 6-in. pot, sprig & 1997 and 1998 \\
\hline Flatstem spikerush & Eleocharis macrostachya & Emergent & 4-in. pot & 1997 and 1998 \\
\hline Squarestem spikerush & E. quadrangulata & Emergent & 4-in. pot & 1997 and 1998 \\
\hline Slender spikerush & E. acicularis & Emergent & 4-in. pot & 1998 \\
\hline Softstem bulrush & Scirpus validus & Emergent & 6-in. pot & 1997 and 1998 \\
\hline Creeping burhead & Echinodorus cordifolius & Emergent & 4-in. pot & 1997 and 1998 \\
\hline Tall burhead & E. berteroi & Emergent & 4-in. pot & 1998 \\
\hline Water hyssop & Bacopa monnieri & Emergent & 4-in. pot & 1998 \\
\hline Water pepper & Polygonum hydropiperoides & Emergent & 4-in. pot & 1998 \\
\hline
\end{tabular}

\section{Assessments}

Assessments of plantings were made at 8-week intervals following planting. Assessments included observations of species survival and growth inside and outside protected areas, and spread from protected areas. In addition, condition of exclosures was examined, and repairs were made when necessary.

\section{7 results}

Individuals of all species except for American lotus planted in June had survived transplanting and were growing inside protected areas by October 1997. Table 3 provides survival percentages of protected and unprotected plants installed outside of large-scale exclosures. Most individuals in tomato, lily, or orange cages had survived and had grown to completely fill those cages. In cases where small-scale exclosures were located within large-scale exclosures, some species exhibited vegetative spread beyond small-scale exclosures. Additionally, new colonies of several species were observed in protected areas, presumably arising from spread of fragments or seeds. Very little spread by any species was observed from small-scale exclosures planted outside of large-scale exclosures; where it did occur, it was apparent that plants had been grazed by common 


\begin{tabular}{|c|c|c|}
\hline \multicolumn{3}{|c|}{$\begin{array}{l}\text { Table } 3 \\
\text { Survival of Protected and Unprotected Plants Outside of Large-scale } \\
\text { Exclosures } 3 \text { Months after Planting in } 1997 \text { (Plants were protected by } \\
\text { tomato or orange cages) }\end{array}$} \\
\hline Common Name & Percent Survival (protected) & Percent Survival (unprotected) \\
\hline Wild celery & 61 & 0 \\
\hline Sago pondweed & 82 & 0 \\
\hline American pondweed & 96 & 0 \\
\hline Water stargrass & 92 & 0 \\
\hline Elodea & 54 & 0 \\
\hline Coontail & 100 & 0 \\
\hline Spatterdock & 100 & 0 \\
\hline White water lily & 67 & 0 \\
\hline American lotus & 0 & 0 \\
\hline Arrowhead & 52 & 0 \\
\hline Bulltongue & 100 & 16 \\
\hline Water willow & 100 & 100 \\
\hline Flatstem spikerush & 100 & 10 \\
\hline Squarestem spikerush & 100 & 0 \\
\hline Softstem bulrush & 100 & 10 \\
\hline Creeping burhead & 100 & 0 \\
\hline
\end{tabular}

carp or turtles. In many cases, southern naiad and muskgrass were present in tomato and orange cages, apparently growing from seed and spores introduced with potted plants.

No breaches in the pens were observed, and herbivores were successfully excluded from plant colonies during this growing season. Submersed plants had grown to nearly fill the pens, but spread outside was minimal, apparently prevented by heavy grazing (by common carp or turtles). Submersed and floatingleaved plants installed inside cove fences had survived, but most showed signs of herbivory and were not as vigorous as nearby plants in tomato and orange cages. Although no breaches were found in the cove fences, small numbers of common carp were observed inside fenced coves, likely contributing to poor success of plants not protected by smaller cages.

American pondweed and water stargrass were the most successful submersed species tested. Both exhibited high survival following initial plantings and had grown to outside cages at some sites. New colonies of each were found throughout several sites. Wild celery was also successfully established within some cages but had not yet to begin spreading (the species is slower growing than others). Elodea and sago pondweed exhibited marginal survival and may have been impacted by small herbivores such as crayfish. However, new colonies of sago pondweed, growing from seeds or fragments, were found behind cove fences at two sites. Coontail had survived, but plants had not spread and were declining within the protective exclosures. It appeared that wave action was breaking the plants into fragments faster than the colonies could replenish their biomass. Southern naiad and muskgrass were commonly observed in association with most plantings, but colonies were limited to tomato and orange cages and were not generally found growing independently in larger exclosures. Spatterdock and 
white water lily survival was high, and both had filled cages but were not spreading beyond. American lotus did not survive the initial plantings. The propagules used to establish this species (10-cm (4-in.) potted plants) were evidently not strong enough to survive transplanting. Emergent species exhibited high survival (inside cages), and many had grown to fill tomato cages. Additionally, several species exhibited some survival without protection. Water willow, already present in the lake, exhibited 100-percent survival, whether protected or not. Some individuals of other species, including bulltongue, flatstem spikerush, and softstem bulrush, had survived but were damaged by grazers and apparently in decline.

Two propagule types of wild celery and American pondweed were tested during 1997, with potted plants and tubers of both species planted in tomato cages at several sites. In both species, tubers had initially sprouted and exhibited some growth, but none were surviving by October. Potted plants, on the other hand, survived transplanting and were established inside tomato cages in October. Additional planting of tubers for these or other species was not attempted during the remainder of this project.

Most species of aquatic plants tested in El Dorado Lake during 1997 survived, grew, and spread successfully within protective herbivore exclosures by the end of the growing season. At some sites, new colonies were developing near the original transplants, exhibiting the early stages of founder colony spread. At that time, it was anticipated that spring regrowth would serve to sustain and increase currently established vegetation. The protective fencing and cages proved adequate and necessary for initial establishment in most cases, and the materials held up well during their deployment.

\section{8 results}

During 1998, plant establishment efforts and assessments were focused primarily on founder colony formation, including establishment and spread of colonies within protected areas for eventual spread to unprotected areas within the lake. Additional plantings of species showing the most success in 1997 were undertaken, and protected areas in most sites were expanded to achieve this goal. Postdormancy recovery and second-year survival of species installed during 1997 were also monitored during 1998.

The lake was visited in early June 1998. Some cages and pens had suffered damage during high spring waters, mostly from floating logs. Fenced coves had been breached by beavers during the winter, and common carp had entered the protected areas in large numbers. Efforts were made to repair the breaches and remove the carp from these areas, including herding, carp baits, and gill netting. For the most part, these efforts were successful. Water levels had risen above some pens during the winter, and small numbers of carp were trapped inside several of these after water levels returned to conservation pool. These carp were hand-removed.

Expansion and modifications of protected areas were made to increase founder colony sizes. Modifications to existing structures included tying pens 
together and constructing extensions of fencing to enclose the water between pens and the shoreline. New construction included shoreline fences (Figure 4), in which fences were installed parallel to the shoreline and to a depth ranging from 1 to $1.2 \mathrm{~m}$, dependent upon the site. The backs of these fences were not enclosed, offering protection only from water-borne grazers.

Following repairs and new construction, more plants were installed at the sites to accelerate the process of establishing founder colonies for further spread throughout the lake. Additionally, several previously untested plant species were added to the planting schedule, including tall burhead (Echinodorus berteroi), pickerelweed (Pontederia cordata), slender spikerush (Eleocharis acicularis), water hyssop (Bacopa monnieri), water pepper (Polygonum hydropiperoides), and Illinois pondweed (Potamogeton illinoensis). A different propagule type for American lotus (stolon tip, rather than $10-\mathrm{cm}$ (4-in.) potted seedling) was also tested. As in 1997, new plants installed were protected by one or two levels of cages, except for a small number of each (testing for the need for protection). In some cases, apical tips were harvested from small-scale protected colonies and used to replant empty tomato, lily, or orange cages, or planted in larger areas behind cove fences. In addition, American pondweed apical tips harvested from a nearby farm pond were planted behind cove fences by KDWP.

By July 1998, water levels had fallen to 407-m (1,335-ft) msl, more than $1 \mathrm{~m}$ below conservation pool. All protected areas and plants were exposed to desiccation at that time. Rainfall in August brought the lake back to conservation pool, and many plants had recovered by October. Several holes dug under fences by beaver were found along cove fences during the low-water period, and these were repaired. Following reflooding, small numbers of common carp were occasionally observed inside the fenced coves and removal techniques were engaged with limited success. Assessments were made in October, which included GPS mapping of planted sites. Table 4 represents a summary of plant colony (species) survival based upon level of protection after two growing seasons.

Potted plants (submersed) installed inside of the newly protected areas (areas between pens; shoreline fences; etc.) established and spread within protected areas quickly. Additionally, colonies of submersed plants inside pens (established in 1997) spread into newly protected areas between them. Colonies declined during low-water levels, but by the end of the growing season, many of these areas were filled or nearly filled with plants. Spread to unprotected areas from these colonies was occasionally observed, but large-scale spread was apparently inhibited by grazing.

Plants behind cove fences were limited to small colonies within tomato cages in early 1998. After common carp densities were reduced and fences repaired, new potted plants and apical tips were installed. These plants initially established well, regardless of being additionally protected with tomato cages, while at the same time existing colonies began to spread from tomato cages. However, breaches in the cove fences evidently allowed entry by common carp, and some of these colonies were in decline before falling water levels left them exposed in August. New breaches in the fences were repaired during low-water conditions. 


\begin{tabular}{|c|c|c|c|c|c|c|c|}
\hline \multicolumn{8}{|c|}{$\begin{array}{l}\text { Table } 4 \\
\text { Colony Survival at End of 1998-Growing Season in El Dorado Lake, Kansas (No data } \\
\text { indicates this level of protection was not tested for a given species. Pot sizes are } \\
\text { nominal.) }\end{array}$} \\
\hline Common Name & Type & $\begin{array}{l}\begin{array}{l}\text { Tomato } \\
\text { Cage }\end{array} \\
\end{array}$ & \begin{tabular}{|l}
$\begin{array}{l}\text { Orange } \\
\text { Cage }\end{array}$ \\
\end{tabular} & Pen & \begin{tabular}{|l} 
Shoreline \\
Pen \\
\end{tabular} & \begin{tabular}{|l}
$\begin{array}{l}\text { Fenced } \\
\text { Cove }\end{array}$ \\
\end{tabular} & $\begin{array}{l}\text { No } \\
\text { Protection }\end{array}$ \\
\hline Wild celery & 4-in. pot & No & Yes & Yes & Yes & No & No \\
\hline Sago pondweed & Tuber & No & No & No & No & No & No \\
\hline \multirow[t]{3}{*}{ American pondweed } & 4-in. pot & Yes & Yes & Yes & Yes & Yes & No \\
\hline & \begin{tabular}{|l} 
Tuber \\
\end{tabular} & No & Yes & No & No & No & No \\
\hline & Apical tip & Yes & No & No & No & No & No \\
\hline Illinois pondweed & 4-in. pot & Yes & & Yes & Yes & Yes & No \\
\hline \multirow[t]{2}{*}{ Water stargrass } & 4-in. pot & Yes & Yes & Yes & Yes & Yes & No \\
\hline & Apical tip & Yes & & Yes & & No & No \\
\hline Elodea & 4-in. pot & No & Yes & Yes & \begin{tabular}{|l|} 
No \\
\end{tabular} & No & No \\
\hline Coontail & Apical tip & No & & & & & \\
\hline Spatterdock & 6-in. pot & Yes $^{1}$ & & & Yes & Yes & No \\
\hline White water lily & 6-in. pot & Yes $^{1}$ & & & Yes & Yes & No \\
\hline \multirow[t]{2}{*}{ American lotus } & 4-in. pot & No & & & No & & No \\
\hline & Stolon tip & & & & Yes & Yes & Yes \\
\hline Arrowhead & 4-in. pot & Yes & & & & Yes & No \\
\hline Bulltongue & 4-in. pot & Yes & & & Yes & Yes & Yes \\
\hline \multirow[t]{2}{*}{ Water willow } & 6-in. pot & Yes & & & Yes & Yes & Yes \\
\hline & Shoots & & & & Yes & & Yes \\
\hline Flatstem spikerush & 4-in. pot & Yes & & & & Yes & Yes \\
\hline Squarestem spikerush & 4-in. pot & Yes & & & & Yes & No \\
\hline Slender spikerush & 4-in. pot & Yes & & & Yes & & No \\
\hline Softstem bulrush & 6-in. pot & Yes & & & Yes & Yes & Yes \\
\hline Creeping burhead & 4-in. pot & Yes & & & & & No \\
\hline Tall burhead & 4-in. pot & Yes & & & & & Yes \\
\hline Water hyssop & 4-in. pot & Yes & & & & Yes & Yes \\
\hline Pickerelweed & 6-in. pot & Yes & & & & Yes & \\
\hline Water pepper & 4-in. pot & Yes & & & & Yes & No \\
\hline
\end{tabular}

Colonies established from potted plants inside (1997 and 1998) and outside (1998) of tomato cages recovered after water returned to normal levels. However, colonies started from apical tips had not recovered, suggesting that plant development was insufficient to withstand the period of desiccation that had occurred. Spread from cove fences to unprotected areas was not observed. Potted plants and apical tips installed in shoreline fences had also become well established initially, forming large colonies (individuals were no longer distinguishable). None of these was additionally protected with tomato cages. No declines were observed before exposure in August, and many species recovered and were filling the protected areas after water levels returned to normal. Greater establishment and recovery success in pens and shoreline fences (relative to cove fences) was attributed to the absence of, or much lower densities of, common carp. Evidently, fences across an entire cove were more susceptible to damage by floating debris (logs, etc.) and beaver activity, both of which permitted entry by common carp.

American pondweed and water stargrass again were the most successful submersed species during the second year. Both established and began to spread within protected areas, and new colonies of both (from fragments or seeds) were 
found in shallow water behind all cove fences. In addition, both species recovered from low-water conditions. Illinois pondweed established quickly in protected (unbreached) areas but did not fair well when breaches occurred. Recovery of Illinois pondweed following low water was poor. Wild celery failed to establish well during 1998, although a few colonies planted in 1997 remained strong and recovered from low-water conditions. Very little sago pondweed and no elodea or coontail were observed by the end of 1998. Several southern naiad and muskgrass colonies were observed in tomato and orange cages following the low water period, and in some cases, these had spread beyond small-scale exclosures.

Most spatterdock and white water lily planted in 1997 had not survived, and cages were replanted with those same species. Additional plants were installed at modified and new protected areas. Spatterdock failed to establish well and did not survive the low-water period in August. White water lily, however, had become established, and many colonies recovered following low-water levels. American lotus planted from apical tips exhibited a high survival rate (about 75 percent) in 1998, and several of the colonies had grown to fill lily cages and beyond, whether inside or outside large-scale exclosures.

As seen in 1997, emergent species exhibited high survival in cages and most had grown to completely fill tomato cages. Additionally, several species (water willow, bulltongue, arrowhead, flatstem spikerush, and softstem bulrush) exhibited survival without protection, and these had begun to grow beyond tomato cages into both large-scale protected and unprotected areas. Several species, including bulltongue, arrowhead, flatstem spikerush, and softstem bulrush were beginning to spread (from seed) behind cove fences. New species tested in 1998 (tall burhead, pickerelweed, slender spikerush, water hyssop, and water pepper) exhibited high survival in protected areas, with water hyssop and water pepper spreading from cages into larger-scale protected and unprotected areas. A test was conducted (June 1998) to ascertain whether water willow could be more efficiently spread by transplanting portions of existing colonies in the lake. Rooted shoots were harvested from small colonies and planted inside and outside several protected areas. In both cases, survival was 100 percent. GPS mapping was conducted at all sites during October 1998 final assessment.

Founder colonies were established at most sites in El Dorado Lake by the end of the second growing season. Several species of aquatic plants survived, grew, and spread successfully within protective exclosures. At some sites, new colonies of some species were developing near the original transplants, exhibiting the early stages of founder colony spread. These colonies not only withstood lowwater conditions, but also were able to spread in the presence of grazers. Some species were not exhibiting spread beyond protective areas, but colonies had survived low-water conditions and intermittent periods of grazing (following breaches in cages). Table 5 provides the species comprising established founder colonies in El Dorado Lake. 


\begin{tabular}{|c|c|c|}
\hline \multicolumn{3}{|c|}{$\begin{array}{l}\text { Table } 5 \\
\text { Species Considered Established as Founder Colonies in El Dorado } \\
\text { Lake after Two Growing Seasons }\end{array}$} \\
\hline Common Name & Growth Form & Protection \\
\hline American pondweed & Submersed & Large- and small-scale \\
\hline Water stargrass & Submersed & Large- and small-scale \\
\hline White water lily & Floating-leaved & Large- and small-scale \\
\hline American lotus & Floating-leaved & Large- and small-scale \\
\hline Bulltongue & Emergent & Small-scale \\
\hline Arrowhead & Emergent & Small-scale \\
\hline Water willow & Emergent & None \\
\hline Flatstem spikerush & Emergent & Small-scale \\
\hline Water hyssop & Emergent & Small-scale \\
\hline Squarestem spikerush & Emergent & Small-scale \\
\hline Softstem bulrush & Emergent & Small-scale \\
\hline
\end{tabular}




\section{Site-by-Site Results}

\section{Site Assessments}

This section provides portions of assessments made at each site during 1997 and 1998. Because this project was primarily an operational, not a scientific, endeavor, this information is included to lend insight to the relative successes and failures encountered during the course of the project. Information given here represents a summary of field observations and should only be considered empirical. Observations included here were made during visits to El Dorado Lake on October 27, 1997, June 4, and October 23, 1998.

\section{Site 1a}

Initial design included 2 pens (planted with American pondweed, water stargrass, sago pondweed, wild celery, and elodea) and 12 tomato cages, each originally planted with American lotus in 1997 but, replanted with water stargrass 8 weeks before the October 1998 assessment.

a. October 1997. American pondweed had grown well in both pens, covering about 50 percent of each and spreading outside the pens. Water stargrass was healthy, but spread was limited to three new colonies within each pen. Elodea was visibly (from the surface) covering 100 percent of one pen, with no evident spread to the outside. Elodea in the other pen had also grown and was visibly covering about 25 percent of the pen. Wild celery and sago pondweed were not evident in either pen. These pens were constructed in shallow water (about $50 \mathrm{~cm}$ deep), and the lake was $20 \mathrm{~cm}$ low during the visit. Overall, the plants grew best in these two pens relative to all pens at other sites. Tomato cages at this site were originally planted with American lotus, which had not survived transplanting and were replanted with water stargrass in mid-August. All plants were doing well. Cages were in shallow water (about $20 \mathrm{~cm}$ deep), and water stargrass stems and leaves were short. Nevertheless, the plants had spread to fill the cages. Unprotected American pondweed and water stargrass colonies were present in shallow waters (less than $15 \mathrm{~cm}$ ) in the back of the cove. Water stargrass was in the deeper water $(10$ to15 cm) and was more abundant than American pondweed, which was in shallower water (less than $10 \mathrm{~cm}$ deep). Southern naiad and muskgrass were observed in both pens and most tomato cages. Overall, the plants at this site were doing well. The colonies formed toward the back of the 
cove suggested that plants were capable of spreading naturally in the lake.

b. June 1998. Plants inside the two pens had recovered following winter, and neither pen was breached. American pondweed remained the dominant plant, but water stargrass, elodea, wild celery, and southern naiad were also present. No significant spread from the cages was noted, but small colonies of American pondweed and water stargrass were visible throughout the cove in water less than $30 \mathrm{~cm}$ deep. The pens were joined to form a larger 10- $\times$ 40-m exclosure. Potted plants added to the newly protected area included American pondweed, water stargrass, wild celery, elodea, and Illinois pondweed. An 85-m cove fence was constructed at the mouth of the cove. Rooted sprigs were harvested from the pens, and American pondweed, water stargrass, and elodea were planted throughout the cove. A 3-m-diam lily cage was constructed within the protected portion of the cove and planted with white water lily and spatterdock. Softstem bulrush, arrowhead, bulltongue, flatstem spikerush, squarestem spikerush, slender spikerush, creeping burhead, tall burhead, and pickerelweed were planted along the shoreline and protected with tomato cages. A third pen was constructed adjacent to existing pens as part of a largemouth bass habitat study conducted by University of Kansas Fisheries biologists. This pen was not planted.

c. October 1998. American pondweed, water stargrass, and southern naiad had grown to fill pens and the protected area between them (Figure 6.). Illinois pondweed, wild celery, and elodea apparently did not survive the low-water period that occurred in August. American pondweed and water stargrass colonies (less than $25-\mathrm{cm}$ in diameter) were scattered throughout the shallow water (20 cm deep and less) at the back of the cove (these were not GPS recorded). White water lily filled one lily cage and spread from the cage was observed. Spatterdock did not survive lowwater conditions that occurred in August. American lotus was surviving in a lily cage but was weak and had not spread. Water willow, bulltongue, arrowhead, water hyssop, flatstem spikerush, and water pepper had filled tomato cages and in most cases spread beyond. In one case, a single bulltongue colony measured $3 \mathrm{~m}$ in diameter. A large arrowhead colony (over $8 \mathrm{~m}$ in diameter) had evidently grown from seed in the back of the cove. Although the cove fence appeared not to be breached, three common carp were removed from inside the protected area. Signs of browsing by deer were noted for both bulltongue and arrowhead at this site.

\section{Site 1b}

Initial design included two pens (planted with American pondweed, water stargrass, sago pondweed, wild celery, and elodea).

a. October 1997. These pens were the deepest of the project (1.2 m). No plants had been observed in the pens before this visit, but in one pen, two healthy American pondweed colonies were noted. Deeper water, high 


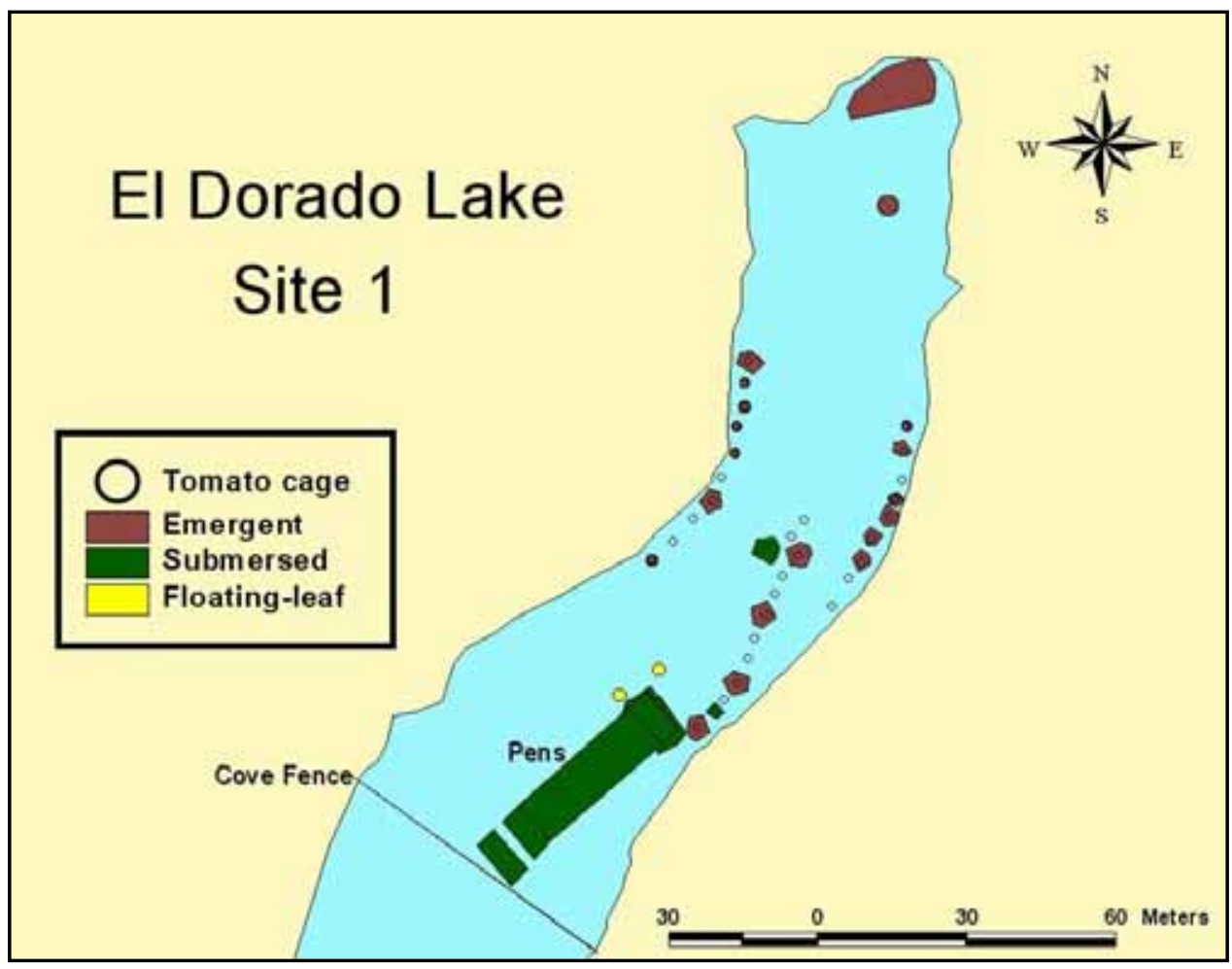

Figure 6. GPS map of Site 1a, El Dorado Lake, October 1998

turbidity, and low light perhaps combined to result in poor establishment at this site.

b. June 1998. American pondweed covered approximately 50 percent of each pen. Neither pen was breached. The pens were joined to form a larger 10- $\times$ 40-m exclosure. Potted plants added to the newly protected area included American pondweed, water stargrass, wild celery, elodea, and Illinois pondweed.

c. October 1998. No plants were observed in these pens, which had been heavily damaged by floating debris (logs). GPS mapping was not conducted at this subsite.

\section{Site 2}

Initial design included two pens (planted with American pondweed, water stargrass, sago pondweed, wild celery, and elodea) and 12 tomato cages (planted with coontail). A row of large, round hay bales was installed at this site to serve as a wave barrier.

a. October 1997. American pondweed was dominant in both pens, covering about 50 percent of each, with some spread outside the pens. Water stargrass covered about 25 percent of each pen. Other species planted were not visible. River bulrush (Scirpus sp.) was established in one corner of one pen. No coontail was observed in the tomato cages, but two 
were colonized by American pondweed (from fragments drifting from the pens), and four were colonized by southern naiad (Najas guadalupensis). Four American pondweed colonies were found in shallow water in the back of this cove (the "cove" formed by the line of hay bales along an old roadbed). Plants here were well established. The open-water conditions (high energy, exposure to herbivores in deeper water) may have inhibited establishment of additional colonies.

b. June 1998. American pondweed dominated the pens, although water stargrass was abundant. Wild celery, elodea, and southern naiad were present in both pens. Neither pen was breached. The tomato cages (originally planted with coontail) were empty, probably because of excessive wave action following disintegration of the hay bale wave break. The pens were joined to form a larger 10- $\times$ 40-m exclosure. Potted plants added to the newly protected area included American pondweed, water stargrass, wild celery, elodea, and Illinois pondweed. A 3-mdiam lily cage was constructed within the wind-protected portion of the cove and planted with white water lily and spatterdock. Empty tomato cages were replanted with American pondweed and Illinois pondweed. A third pen was constructed adjacent to existing pens as part of a largemouth bass habitat study conducted by University of Kansas Fisheries biologists. This pen was not planted.

c. October 1998. Both pens were damaged at this site (from floating debris), and repairs were made. However, pens (and the protected area between them) exhibited 100 percent plant coverage, with American pondweed, water stargrass, river bulrush, and southern naiad dominating (Figure 7). Wild celery and Illinois pondweed were also present at this site: the substrate evidently remained moist enough during low-water conditions, resulting in survival of these desiccation-intolerant species. Many of the tomato cages were damaged and had no plants associated with them. American and Illinois pondweeds were present in undamaged cages, but none exhibited evidence of spread. White water lily had filled the lily cage but was not spreading. Spatterdock and American lotus did not survive at this site.

\section{Site $3 a$}

Initial design included two pens (planted with American pondweed, water stargrass, sago pondweed, wild celery, and elodea).

a. October 1997. No plants were observed in these pens before the October visit. These pens were constructed in water nearly 1-m deep and were 75-cm deep at the time of visit. In one pen, two American pondweed colonies were observed. As in Site 1b, low light conditions caused by high turbidity may have slowed establishment of these plants and may have contributed to apparent mortality in the other species.

b. June 1998. American pondweed was present in both pens, covering 100 percent of one and about 75 percent of the other. Neither pen was breached. The pens were joined to form a larger 10- $\times$ 40-m exclosure. 


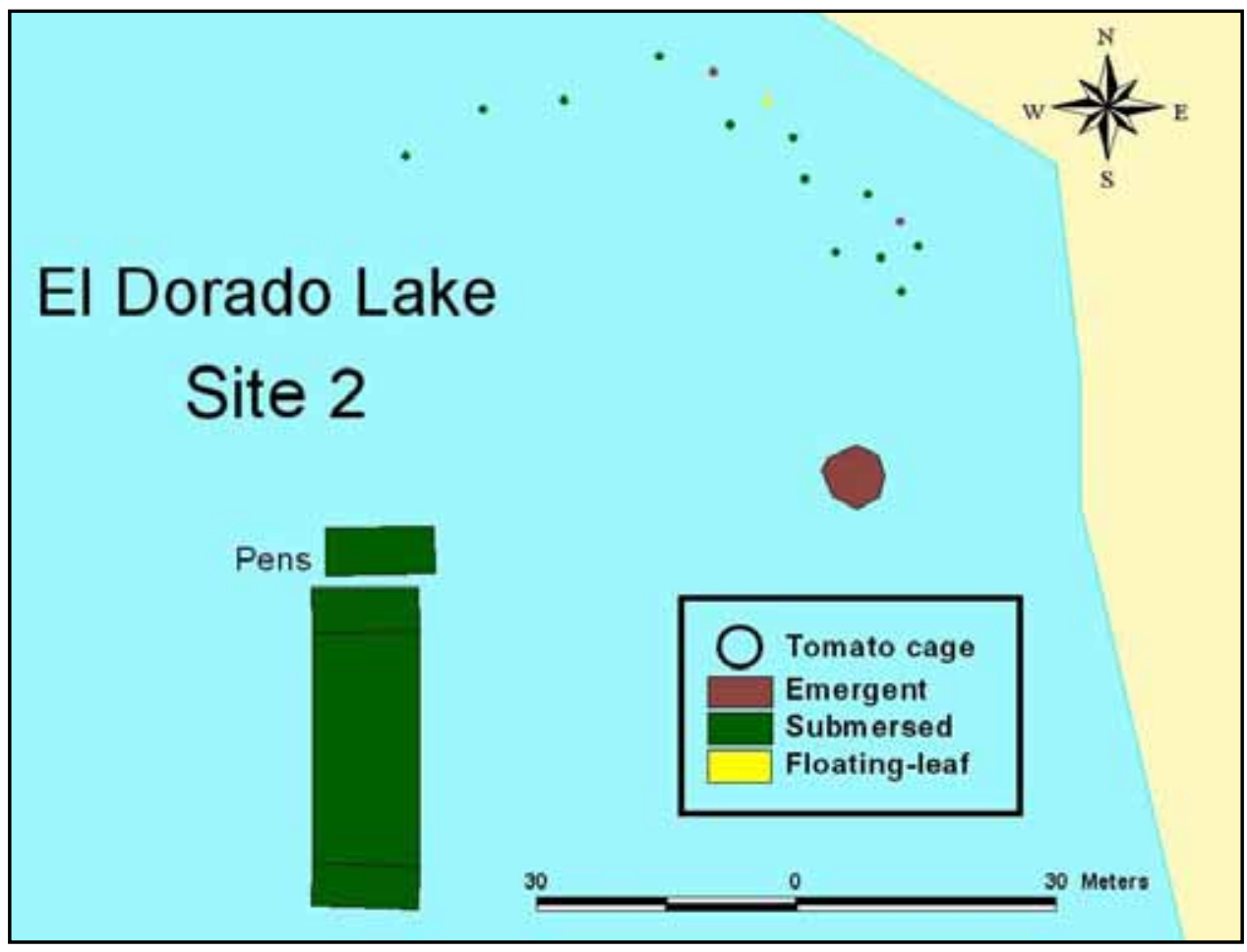

Figure 7. GPS map of Site 2, El Dorado Lake, October 1998

Potted plants added to the newly protected area include American pondweed, water stargrass, wild celery, elodea, and Illinois pondweed. A 3-m-diam lily cage was constructed within the protected portion of the cove and planted with white water lily, spatterdock, and water shield. A 35-m-long shoreline fence was constructed to a depth of about $1 \mathrm{~m}$ and the newly protected area was planted with American pondweed, water stargrass, wild celery, elodea, Illinois pondweed, softstem bulrush, arrowhead, bulltongue, flatstem spikerush, squarestem spikerush, slender spikerush, creeping burhead, tall burhead, and, pickerelweed. American lotus apical tips were planted later at this site. A third pen was constructed adjacent to existing pens as part of a largemouth bass habitat study conducted by University of Kansas Fisheries biologists. This pen was not planted.

c. October 1998. Both pens, the protected area between them, and the lily cage were heavily damaged by floating debris. No plants were observed in these areas. Apparently, recovery following low-water conditions was prevented by herbivory. The shoreline fence was damaged, but evidently not breached. American pondweed and water stargrass colonies had grown to fill an estimated 25 percent of the protected area (Figure 8). Other submersed species planted here did not survive. A colony of American lotus had recovered following low-water conditions in August and was apparently spreading within the shoreline fence. Of the emergent species planted, flatstem spikerush and creeping burhead were present, but had not expanded since planting. Other emergent species were absent. Terrestrial grazers may have entered the shoreline pen from the unprotected shoreward side and contributed to their demise. 


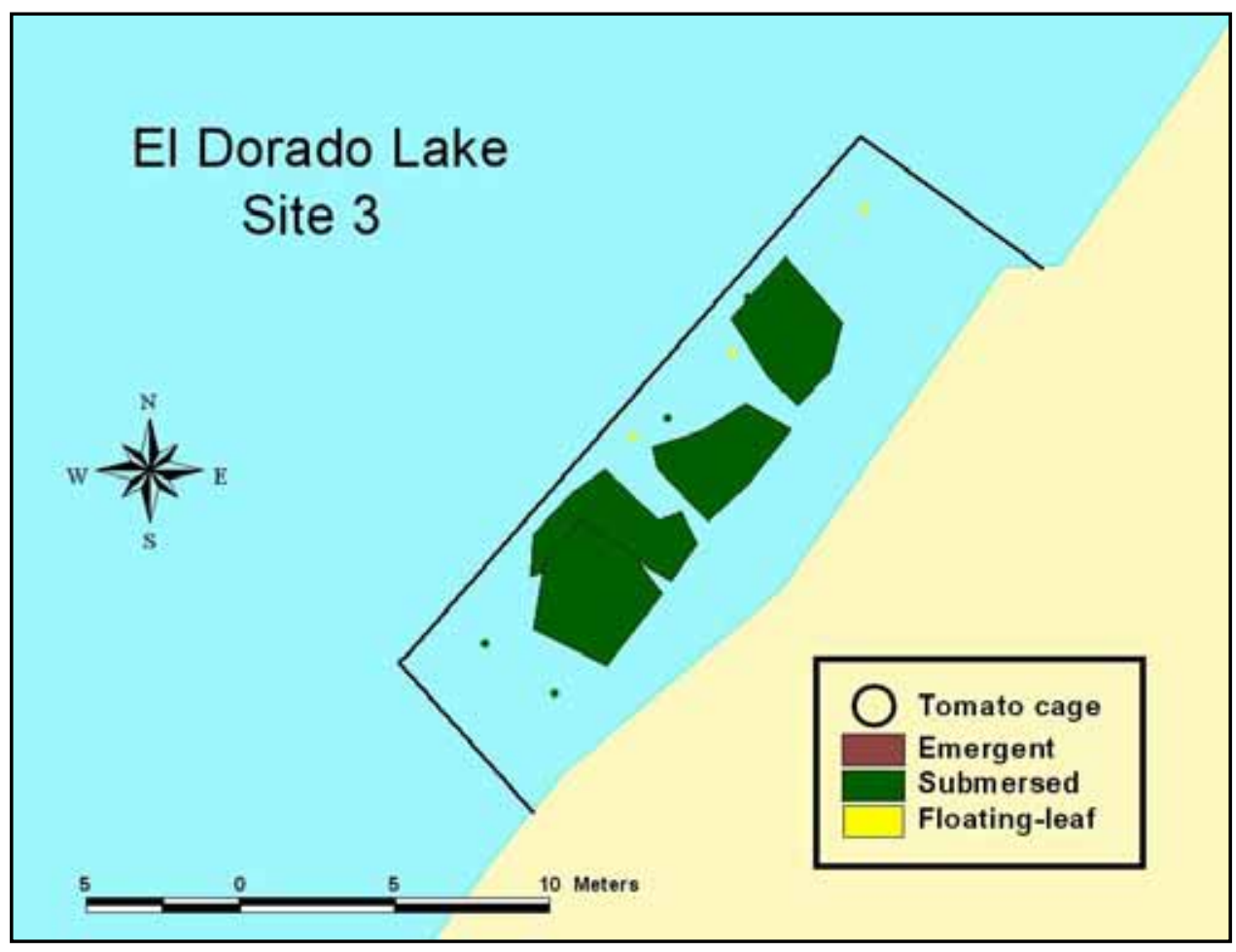

Figure 8. GPS map of Site 3a, shoreline fence in El Dorado Lake, October 1998. Lily cage and pens are not shown

\section{Site 3b}

Initial design included 24 tomato cages (planted with American lotus, white water lily, and spatterdock).

a. October 1997. American lotus did not survive. White water lilies were entering dormancy and were exhibiting submersed leaves. All spatterdock were alive and exhibited submersed leaves. Half the cages support mixed colonies of southern naiad and muskgrass. No spread of any species was noted.

b. June 1998. No plants recovered following the winter. Tomato cages were replanted with American pondweed and Illinois pondweed.

c. October 1998. Some cages were damaged by floating debris. American pondweed was present in cages in which it had been planted (Figure 9). Illinois pondweed did not recover following low-water conditions. Southern naiad was present in most cages.

\section{Site 3c}

Initial design included 48 tomato cages (planted with American pondweed, water stargrass, sago pondweed, wild celery, and elodea; emergent species planted here include softstem bulrush and arrowhead) and a cove fence. 


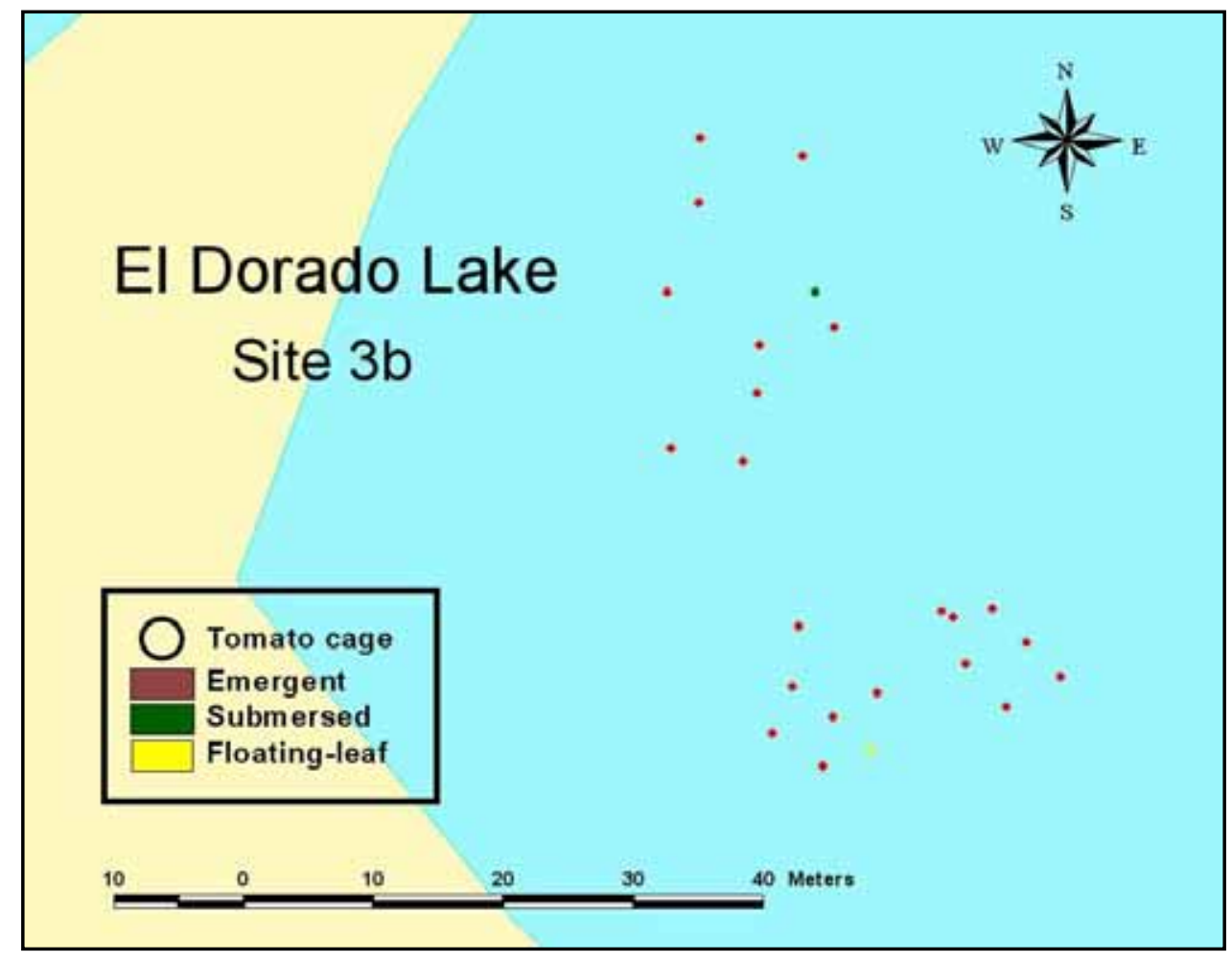

Figure 9. GPS map of Site 3b, El Dorado Lake, October 1998

a. October 1997. Wild celery and elodea had both disappeared, with the losses attributed to high turbidity and herbivory (suspected crayfish). Water stargrass had filled its cages. Two colonies were found in shallow water $(15 \mathrm{~cm})$ outside the cages. Sago pondweed was growing well within its cages. Some spread outside was noted in two of six cages. American pondweed grew well in all cages but one (it was tipped, allowing access from beneath the cage) but was recovering in that cage. Spread from the cages was significant, and the colonies had overlapped to form a continual fringe of plants in the 50- to 75-cm depth contour for a distance of about $10 \mathrm{~m}$. Five colonies were found outside the cages in shallow waters (15 cm deep and less). Some cages supported southern naiad and muskgrass colonies as well as the planted species. For the most part, arrowhead had gone dormant, although a few young plants were visible. No spread of arrowhead was noted, even within cages. Tubers were formed by the plants. Softstem bulrush had filled its cages and had spread a few inches from each. Six bulrush cages were recovering from an herbicide treatment along a road that parallels the cove. Overall, the plants at this site appeared to be established.

b. June 1998. Most plants survived within tomato cages, but spread that had occurred the previous year had been destroyed by herbivores. Common carp evidently breached the fences. The main cove fence was repaired and a secondary fence constructed to prevent access through an adjacent culvert during high-water events. Empty cages were replanted with the same species planted the previous year, with the exception of sago pondweed, which was replanted with Illinois pondweed. New emergent 
species added included bulltongue, flatstem spikerush, squarestem spikerush, slender spikerush, creeping burhead, tall burhead, and pickerelweed, with each protected with tomato cages.

c. October 1998. Cove fences were damaged and common carp were observed inside. American pondweed and water stargrass were present in some of the tomato cages in which they had been planted, but no other submersed species were observed at this site (Figure 10). Softstem bulrush, bulltongue, water hyssop, water pepper, tall burhead, arrowhead, flatstem spikerush, and squarestem spikerush persisted inside of tomato cages. Only bulltongue had spread beyond small-scale protection.

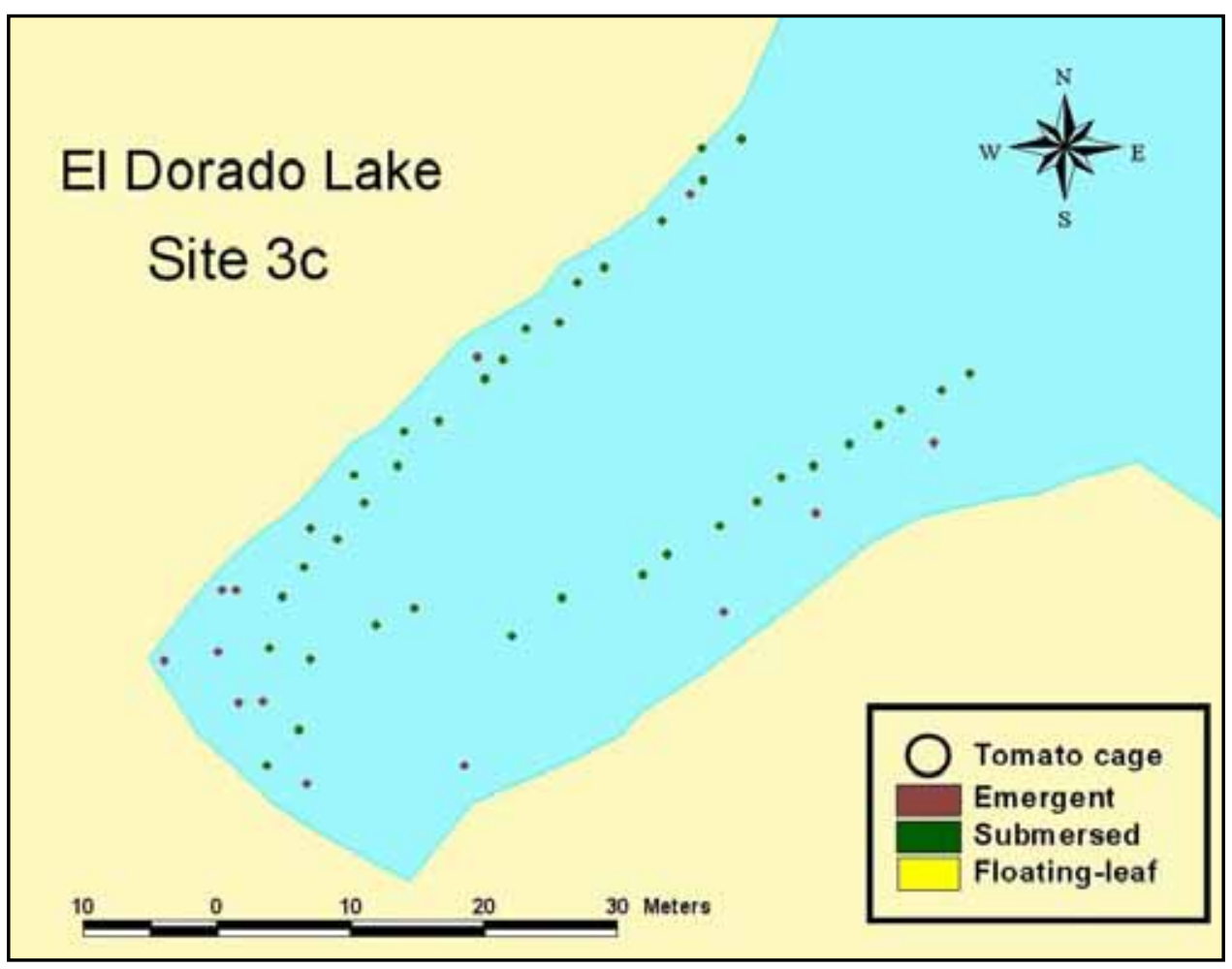

Figure 10. GPS map of Site 3c, El Dorado Lake, October 1998

\section{Site 4}

Initial design included two pens (planted with American pondweed, water stargrass, sago pondweed, wild celery, and elodea).

a. October 1997. American pondweed was dominant, covering about 50 percent of each pen. Some spread outside was noted, but these plants appeared to be damaged by common carp. Water stargrass was present, but had not spread within the pens. Some sago pondweed was observed in one pen. Wild celery and elodea were not visible. Small colonies of southern naiad were present. Two small colonies of American pondweed were found at the back of the cove at Site 4, indicating potential natural spread in the lake. 
b. June 1998. American pondweed remained the dominant species, with patches of water stargrass and southern naiad present. Neither pen was breached. The pens were joined to form a larger 10- $\times$ 40-m exclosure. Additionally, the ends of the pens were extended to the shoreline to form a large shoreline fence just behind the pens. Potted plants added to the newly protected areas included American pondweed, water stargrass, wild celery, elodea, and Illinois pondweed. In addition, bulrush, arrowhead, bulltongue, flatstem spikerush, squarestem spikerush, slender spikerush, creeping burhead, tall burhead, and pickerelweed were planted in shallow waters behind the shoreline fence. American lotus shoots were added later. A 3-m-diam lily cage was constructed within the protected portion of the cove and planted with white water lily and spatterdock. Two each of softstem bulrush, arrowhead, bulltongue, flatstem spikerush, squarestem spikerush, slender spikerush, creeping burhead, tall burhead, and pickerelweed were planted in a small pocket at the back of the cove this site, and each protected with tomato cages. A third pen was constructed adjacent to existing pens as part of a largemouth bass habitat study conducted by the University of Kansas Fisheries biologists. This pen was not planted.

c. October 1998. American pondweed dominated pens and protected area between them and had spread to fill much of shoreline fence constructed on the shoreward side of the pens. Water stargrass, Illinois pondweed, and southern naiad were mixed with the American pondweed colonies (Figure 11). Most emergent species had survived but were overgrown by water willow expansion, which occurred naturally inside the shoreline fence area. All emergent species planted at the back of the cove in tomato cages had survived, but only bulltongue had grown beyond the small-scale protection.

\section{Site 5}

Initial design included 36 tomato cages (planted with American lotus) installed at 1-m to 1.2-m depths.

a. October 1997. American lotus did not survive transplanting. Water level fluctuations following planting may have contributed to mortality by promoting damage to leaves and stems as they became entangled in tomato cage mesh. Larger-diameter cages might have reduced leaf and stem damage. Several cages supported small colonies of southern naiad. The cages were replanted with American pondweed and water stargrass.

b. June 1998. Several tomato cages were missing or destroyed at the site (evidently by floating branches). In those cages remaining, American pondweed and water stargrass both showed good survival but had not spread. A 40-m-long shoreline fence was constructed (to a depth of $1.2 \mathrm{~m}$ ) to enclose the cages, and additional potted plants were planted behind this fence. Species planted included American pondweed, Illinois pondweed, wild celery, water stargrass, and elodea. In shallower waters behind the fence, bulrush, arrowhead, bulltongue, flatstem spikerush, 


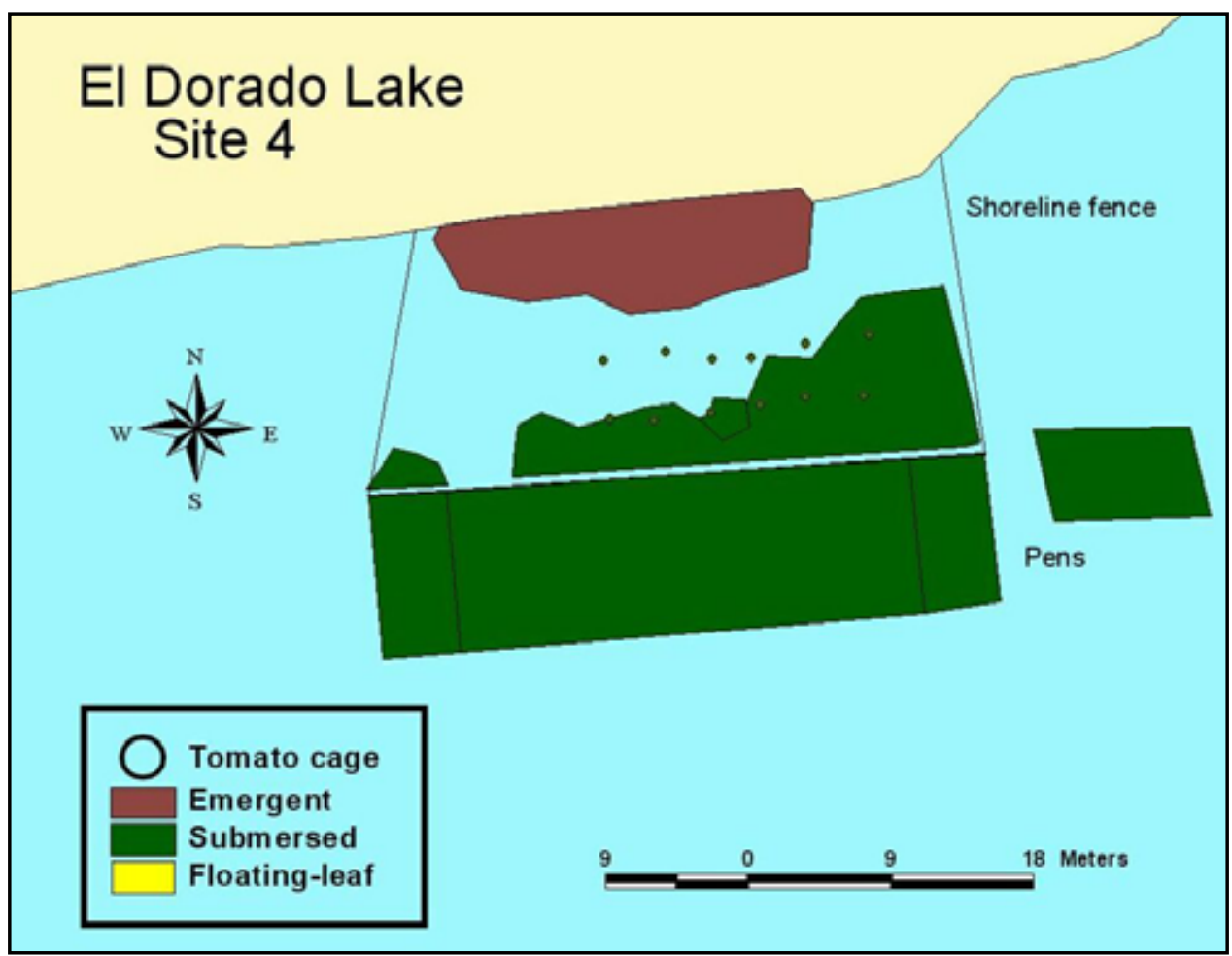

Figure 11. GPS map of Site 4, El Dorado Lake, October 1998

squarestem spikerush, slender spikerush, creeping burhead, tall burhead, and pickerelweed were also planted. Rooted shoots of water willow from nearby colonies were also planted behind this fence. Three each of softstem bulrush, arrowhead, bulltongue, tall burhead, and pickerelweed were planted in a small cove on the north side of the road adjacent to the shoreline fence. Each of these was protected by a tomato cage. Additionally, approximately 200 apical tips of locally collected American pondweed were planted in this cove without protection.

c. October 1998. American pondweed and water stargrass recovered following low-water conditions at this site. These had filled tomato cages in which they were planted and spread beyond, with plants from adjacent cages forming large colonies (Figure 12). One cage each of wild celery and Illinois pondweed survived low water in August, and these had filled cages and had spread beyond tomato cages. All emergent species planted behind the shoreline fence had survived, but none had spread beyond tomato cages. Water willow sprigs planted behind the shoreline fence had established and were beginning to spread. Emergent plants installed in the small cove across the road also survived and filled cages, with bulltongue, arrowhead, tall burhead and pickerelweed beginning to spread beyond protected areas. American pondweed planted from apical tips had disappeared, apparently unable to establish before water levels dropped. Red-eared sliders (Trachemys scripta elegans) were observed at this site, which may have contributed to the failure of American pondweed survival outside protected areas. 


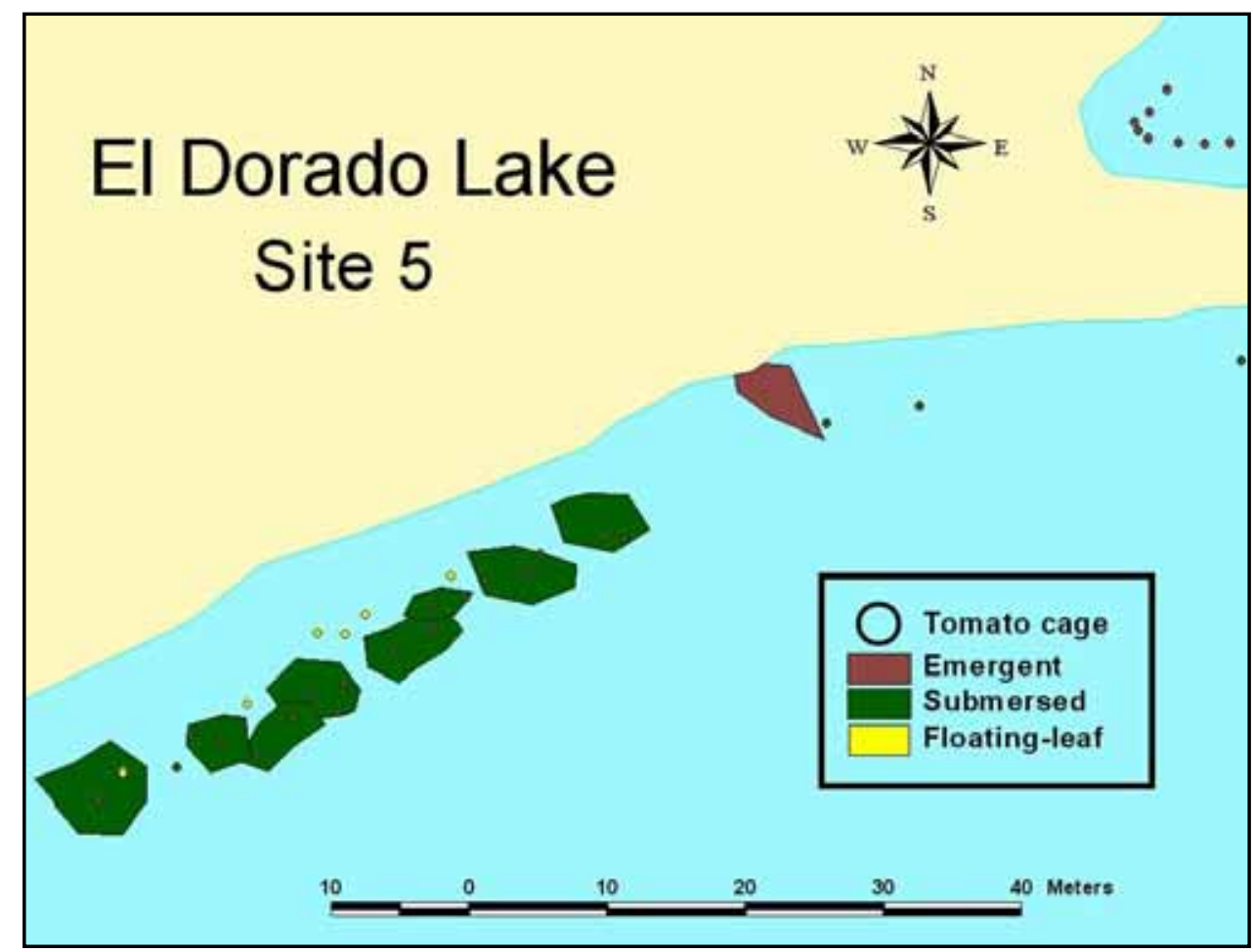

Figure 12. GPS map of Site 5, El Dorado Lake, October 1998. The shoreline fence surrounding tomato cages and plant colonies is not visible on this map

\section{Site 6a}

Initial design included two pens (planted with American pondweed, water stargrass, sago pondweed, wild celery, and elodea) and six tomato cages (planted with various combinations of the five submersed species).

a. October 1997. American pondweed covered about 75 percent of each pen. Water stargrass and cattails covered about 25 percent of one pen. One tomato cage was filled with American pondweed, another with water stargrass. Other cages were empty. Seven patches of American pondweed were found on the shoreline nearest pens, in shallow waters (under $15 \mathrm{~cm}$ deep). One of these colonies measured $2 \mathrm{~m}$ in diameter. Two each of softstem bulrush, arrowhead, bulltongue, flatstem spikerush, squarestem spikerush, creeping burhead, and pickerelweed were planted in shallow waters and protected with tomato cages near the end of the growing season.

b. June 1998. American pondweed continued to dominate the two pens, with water stargrass still present in patches. No breaches were noted in either pen. Cattails had expanded to cover about 40 percent of one pen. Small colonies of American pondweed were evident throughout the general area of the site, even though these were unprotected. Most colonies were in $15 \mathrm{~cm}$ or less of water, indicating that common carp (or turtles) were not feeding at these shallow depths. Emergent species had 
spread from tomato cages, and several colonies of bulltongue exceeded $3 \mathrm{~m}$ in diameter. The pens were joined to form a larger $10-\times 40-\mathrm{m}$ exclosure. Additionally, the ends of the pens were extended to the shoreline to form a large shoreline fence just behind the pens. Potted plants added to the newly protected areas included American pondweed, water stargrass, wild celery, elodea, and Illinois pondweed. In addition, bulrush, arrowhead, bulltongue, flatstem spikerush, squarestem spikerush, slender spikerush, creeping burhead, tall burhead, and pickerelweed were planted in shallow waters behind the shoreline fence. In mid-July, a fence was extended across this cove to protect spreading colonies. Locally collected American pondweed and American lotus shoots were planted at this time. A 3-m-diam lily cage was constructed within the protected portion of the cove and planted with white water lily and spatterdock. A third pen was constructed adjacent to existing pens as part of a largemouth bass habitat study conducted by University of Kansas Fisheries biologists. This pen was not planted.

c. October 1998. American pondweed remained dominant throughout much of the large-scale protected area. Both pens and the protected area between them were filled with American pondweed, although one pen contained about 50 percent cattails (Figure 13). The shoreline fence behind the pens was nearly 50-percent filled with submersed vegetation, primarily American pondweed. Small patches of water stargrass were interspersed throughout the pondweed colonies. Other submersed species were not observed. White water lily filled the lily cage and spread beyond its edges by about $1 \mathrm{~m}$. Spatterdock did not survive the lowwater event in August. American lotus planted from apical shoots had recovered, but colonies remained small (less than $2 \mathrm{~m}$ in diameter). Bulltongue, arrowhead, water hyssop, and squarestem spikerush filled tomato cages and were growing beyond: one bulltongue colony had a 6-m diameter. Other emergent species had survived, but were not spreading from tomato cages (inside or outside shoreline fence). Signs of browsing on emergent species by deer were evident at this site.

\section{Site $6 b$}

Initial design included 18 tomato cages (each planted with combinations of American pondweed, sago pondweed, water stargrass, and wild celery).

a. October 1997. American pondweed dominated all cages, and water stargrass was present in most. Sago pondweed was seen in four cages, and wild celery was not observed. It was reported that several weeks before the October visit, American pondweed had spread outside cages to overlap adjacent cages, forming a large, single colony. Storm events broke up the colony, but many small patches of the species remained between cages. 


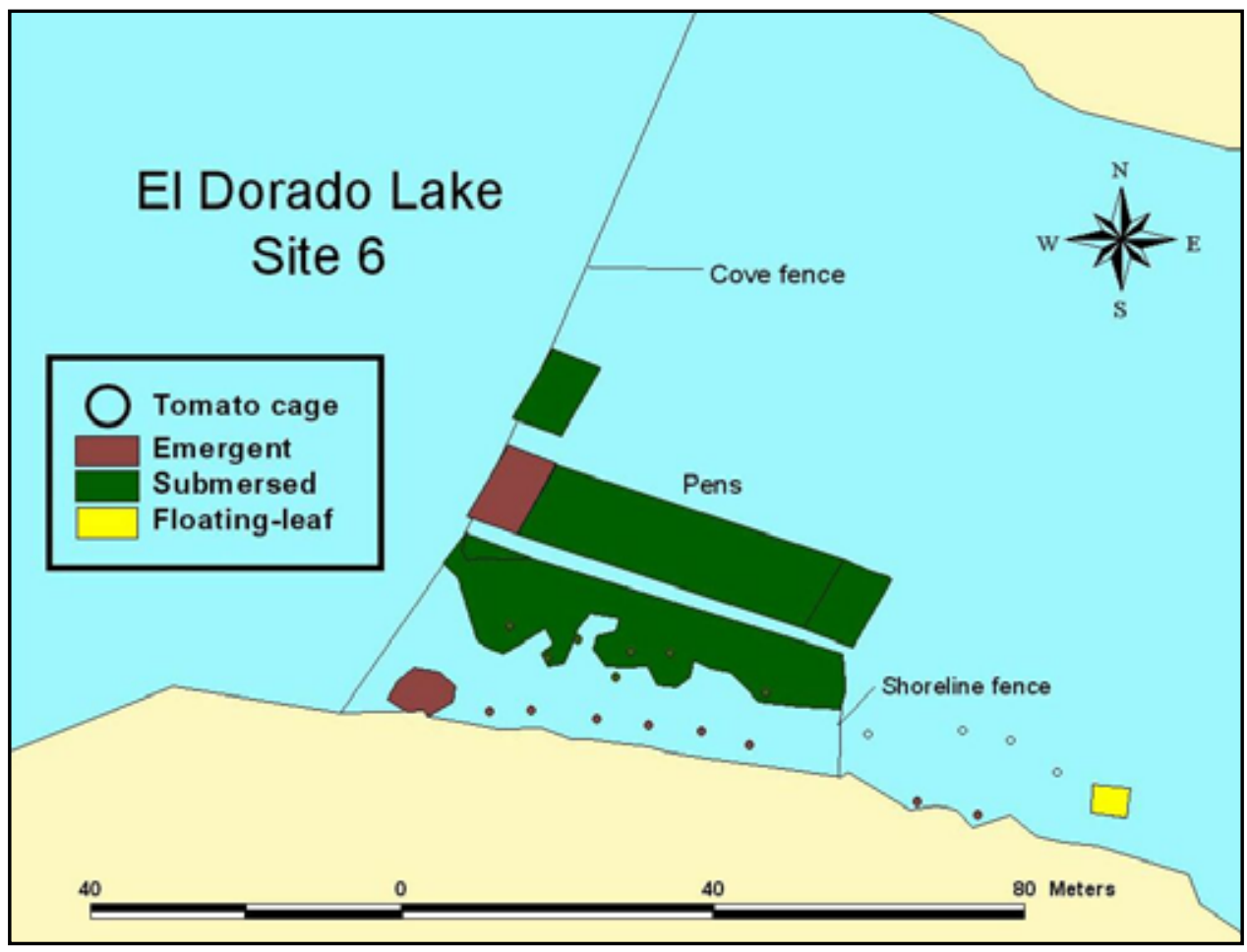

Figure 13. GPS map of Site 6a, El Dorado Lake, October 1998

b. June 1998. American pondweed was present in some cages, but the spread noted the previous year was no longer present. Cages were replanted with American pondweed, Illinois pondweed, wild celery, water stargrass, and elodea.

c. October 1998. Most of the cages were destroyed by floating debris, and several were missing. Most remaining cages supported colonies of American pondweed, although one supported water stargrass (Figure 14). No evidence of spread was noted.

\section{Site 7}

Initial design included three orange cages (each planted with white water lily and American pondweed) constructed in August 1997.

a. October 1997. Plants were well established and beginning to spread outside the cages. Small ( $<1$-m-diam), unprotected American pondweed patches were found in shallow water throughout the small cove.

b. June 1998. White water lily and American pondweed had recovered within cages and were beginning to spread. A fence was constructed across the cove in mid-Spring by KDWP personnel to protect spreading colonies. 


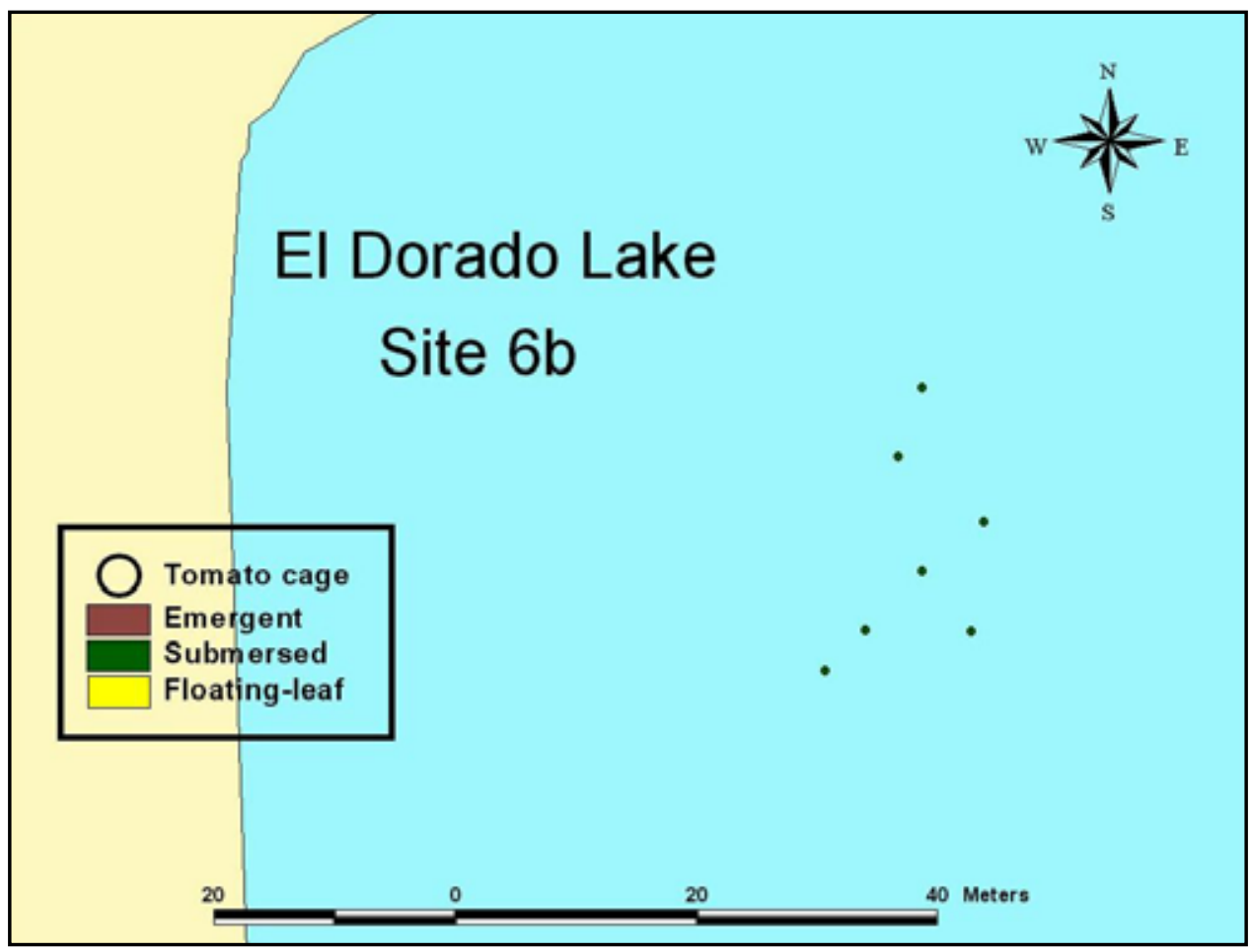

Figure 14. GPS map of Site 6b, El Dorado Lake, October 1998

c. October 1998. American pondweed and white water lily recovered from low-water conditions and continued to spread throughout the cove, despite breaching of the cove fence (Figure 15). Small ( $<1$-m-diam) colonies of American pondweed were found in shallow water $(30-\mathrm{cm}$ deep and less) along much of the cove shoreline. Additionally, several white water lily seedlings were observed at this site. American coot were observed feeding heavily on American pondweed seeds and leaves during this visit.

\section{Site 8}

Initial design included a fenced cove, planted with all tested species, some protected with tomato cages, some protected with orange cages, and some not secondarily protected.

a. October 1997. The cove fence at this site was periodically breached by beavers, with repairs made as necessary. Growth was observed by all submersed species except wild celery (gone dormant or eaten) and elodea (eaten). Ten American pondweed patches, four water stargrass patches, and one southern naiad patch were found in the back of the cove in shallow water. Softstem bulrush exhibited good growth, but little spread. Arrowhead had gone dormant but had produced tubers. The relative slow growth and spread of plants in this cove when compared with other fenced coves indicated that herbivore densities inside the fence were too high for plants to become well established. 


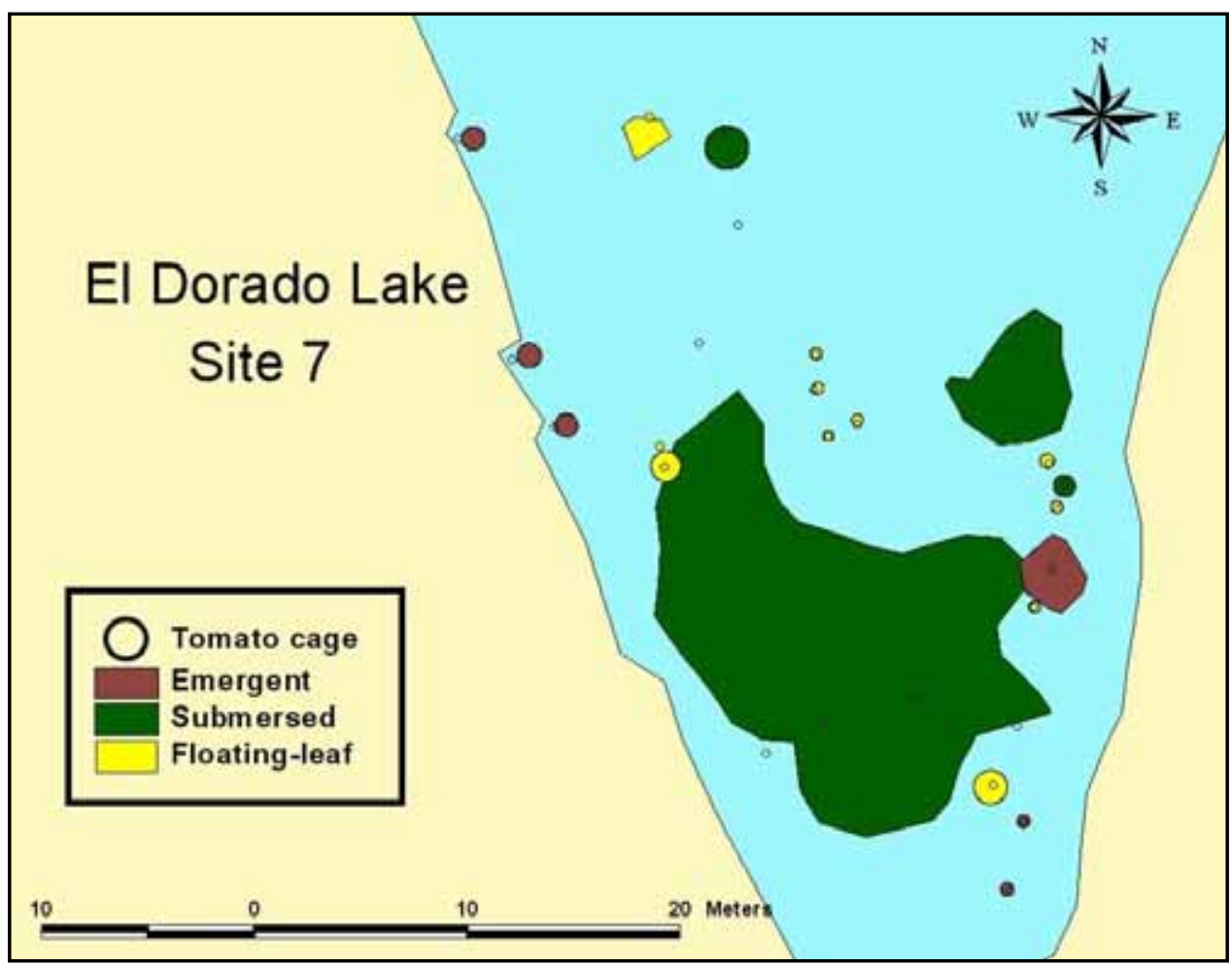

Figure 15. GPS map of Site 7, El Dorado Lake, October 1998. The cove fence is not shown

b. June 1998. Plants had recovered well, with American pondweed the dominant species. Evidence of herbivory was noted. Carp were shooed out, and breaches in the fence were located and repaired. These breaches consisted of channels beneath the fence, dug by beavers. Tomato cages were replanted with original species, and additional tomato cages were constructed and planted with American pondweed, Illinois pondweed, water stargrass, wild celery, and elodea. Additionally, sprigs of American pondweed and water stargrass were planted throughout the cove. White water lily and spatterdock were planted without tomato cage protection. A week following repairs and planting, common carp were observed inside the fence. KDWP initiated a carp management program that included gillnetting and using rotenone-laced bait in this cove. The reduction in carp density resulted in a recovery of many plant colonies within several weeks following implementation. Softstem bulrush and arrowhead cages were replanted with submersed species where survival was low (the cages were originally set too deep for emergent establishment). New tomato cages were constructed and placed in shallower waters, and planted with softstem bulrush, arrowhead, bulltongue, flatstem spikerush, squarestem spikerush, slender spikerush, creeping burhead, tall burhead, and pickerelweed. A shoreline fence was constructed along the south side of the cove, using the fenced cove as one side. The fence was $60 \mathrm{~m}$ long and extended to a depth of $1 \mathrm{~m}$, and was subdivided internally to produce two 30-m fences. Each was planted with potted American pondweed, Illinois pondweed, water stargrass, wild celery, and elodea. 
c. October 1998. Tomato cages and orange cages in deeper water supported American pondweed, water stargrass, and southern naiad colonies (Figure 16). Other submersed species were not observed, and these probably did not survive the low-water conditions in August. American pondweed and water stargrass, both apparently established from seeds and fragments, were abundant in shallower, unplanted areas behind the cove fence. These same two species had grown to nearly fill the shoreline fences constructed adjacent to the cove fence. White water lily remained present behind the cove fence, but exhibited signs of grazing by semiaquatic turtles and had not spread beyond its planting points. Emergent species had all survived and most had grown to fill cages, but few had spread. An interesting case of masking may have occurred at this site: softstem bulrush generally fills tomato cages but does not spread beyond as the result of intense grazing. However, one softstem bulrush colony grew to exceed $3 \mathrm{~m}$ in diameter, apparently because of a colony of water willow had become established around the bulrush, masking it from grazers.

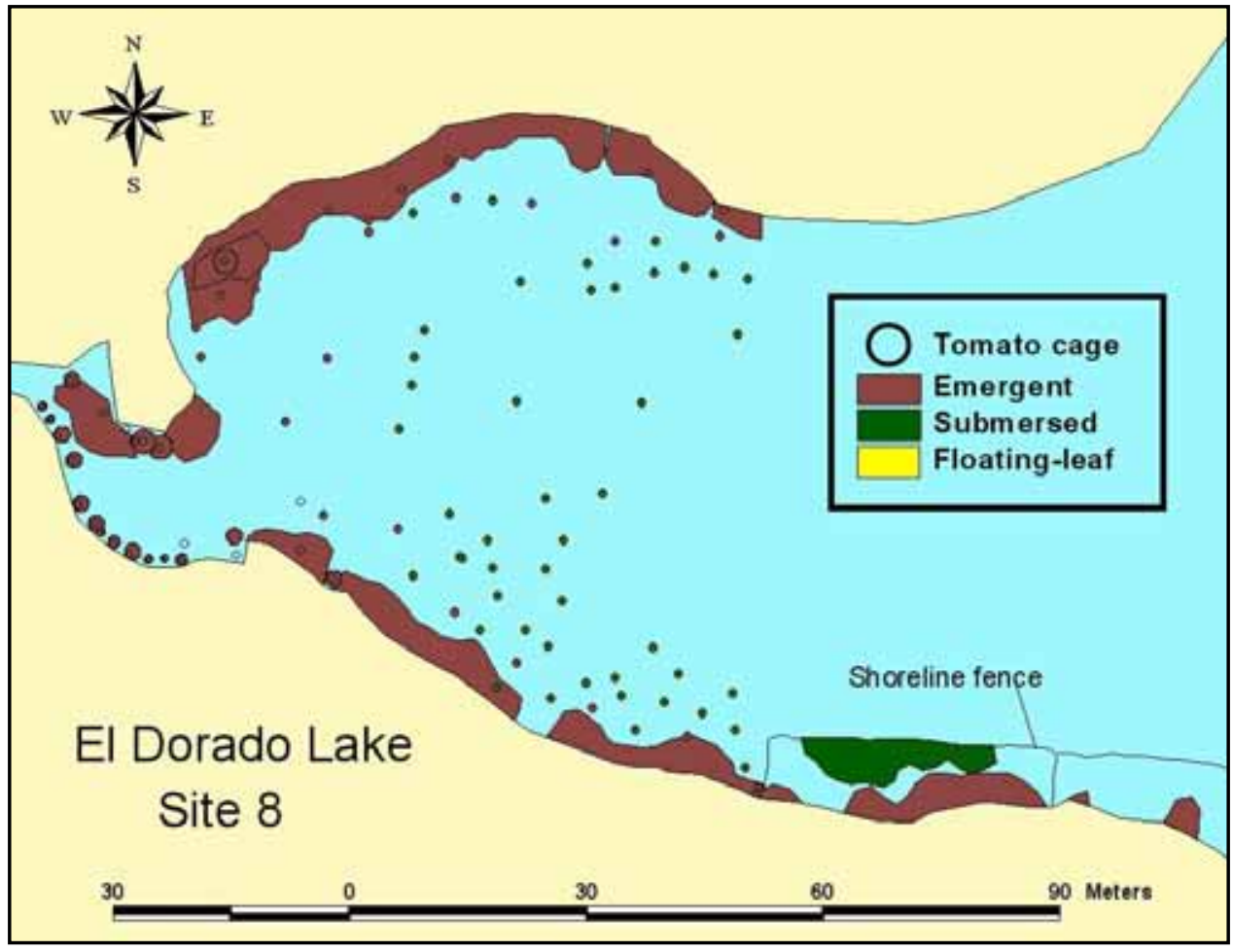

Figure 16. GPS map of Site 8, El Dorado Lake, October 1998

\section{Site 9}

Initial design included tomato cages and orange cages, with no second level of protection (no-fence cove).

a. October 1997. All species except wild celery and elodea did well within tomato and orange cages. There was little or no spread outside cages, 
however, suggesting that the cove fences at other sites were of benefit during initial establishment. Emergent plants did well at this site, suggesting that the aquatic herbivores were not affecting establishment of these species.

b. June 1998. American pondweed and water stargrass were present within cages, but no spread had occurred. Other submersed species cages were empty, and all were replanted with American pondweed, Illinois pondweed, or water stargrass. Two shoreline fences, each 30-m in length, were constructed and planted with potted American pondweed, Illinois pondweed, water stargrass, wild celery and elodea. Additionally, softstem bulrush, arrowhead, bulltongue, flatstem spikerush, squarestem spikerush, slender spikerush, creeping burhead, tall burhead, and pickerelweed were planted in the shallows behind each fence. Softstem bulrush had survived but had not spread. Arrowhead survival was low, and empty cages were replanted with either bulltongue or arrowhead. Water willow sprigs were harvested from near the site and planted throughout the shallows. A 3-m-diam lily cage was constructed within the protected portion of the cove and planted with white water lily and spatterdock.

c. October 1998. American pondweed and water stargrass persisted in tomato and orange cages, and spread from several pondweed cages was observed (Figure 17). Both were also present and had spread inside of shoreline fences. A small colony (2 $\mathrm{m}$ in diameter) of Illinois pondweed was found in one shoreline fence. White water lily completely filled the lily cage. Spatterdock was present, but weak. All emergent species planted inside shoreline fences had survived, and softstem bulrush, water hyssop, and bulltongue had spread beyond initial planting points. Transplanted water willow sprigs survived and were each forming small colonies.

\section{Site 10}

Initial design included a fenced cove, planted with all tested species, some protected with tomato cages, some protected with orange cages, and some not secondarily protected.

a. October 1997. All submersed species were observed except wild celery. Elodea was established in one orange cage. Spread outside cages was seen by American pondweed, with some colonies exceeding $2 \mathrm{~m}$ in diameter. Many small colonies of American pondweed, water stargrass, sago pondweed, and southern naiad were established throughout cove, primarily in water less than $50 \mathrm{~cm}$ deep. Emergent species also grew well. Bulltongue had spread from cages rapidly, with most colonies exceeding $3 \mathrm{~m}$ in diameter. Good spread was noted by both spikerush species and creeping burhead, and some spread of softstem bulrush had occurred. 


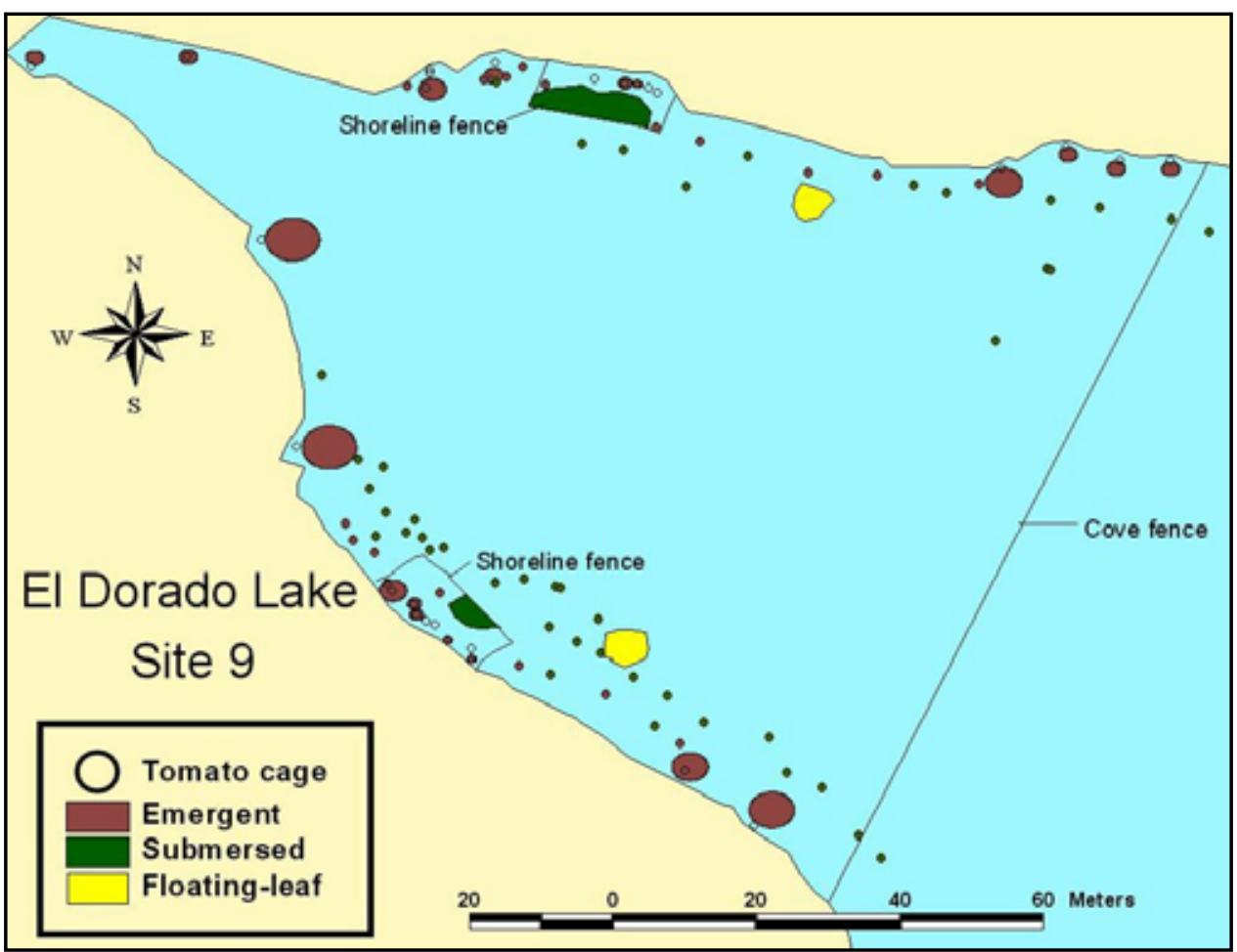

Figure 17. GPS map of Site 9, El Dorado Lake, October 1998

b. June 1998. The fence had been breached by beavers and repaired by KDWP personnel before the planting and assessment date. American pondweed occurred throughout along a fringe in water up to 50-cm deep. Patches of water stargrass were also present. Other submersed species were not observed. Most emergent species had survived well in cages, and spread from many was evident. Illinois pondweed was added to this site, and plants were protected with tomato cages. Emergent species exhibited similar results. American pondweed, water stargrass, and elodea were sprigged throughout the cove. White water lily and spatterdock were added without additional protection. American lotus was added later. A two-tier shoreline fence was constructed along the north side of the cove, using the fenced cove as one side. The fence was $65 \mathrm{~m}$ long and extended to a depth of $1.2 \mathrm{~m}$. It is subdivided internally to produce a shallow and a deep pen. The deep pen was planted with potted American pondweed, Illinois pondweed, water stargrass, wild celery, and elodea. This pen also enclosed the existing orange fences outside the fence cove at the site. The shallow pen was planted with potted American pondweed, Illinois pondweed, water stargrass, wild celery, and elodea, and softstem bulrush, arrowhead, bulltongue, flatstem spikerush, squarestem spikerush, slender spikerush, creeping burhead, tall burhead, and pickerelweed.

c. October 1998. The cove fence was breached several times during the summer by beavers. Common carp were removed with gill nets and the fence was repaired as needed. American pondweed and water stargrass colonies persisted in most tomato and orange cages (Figure 18). 


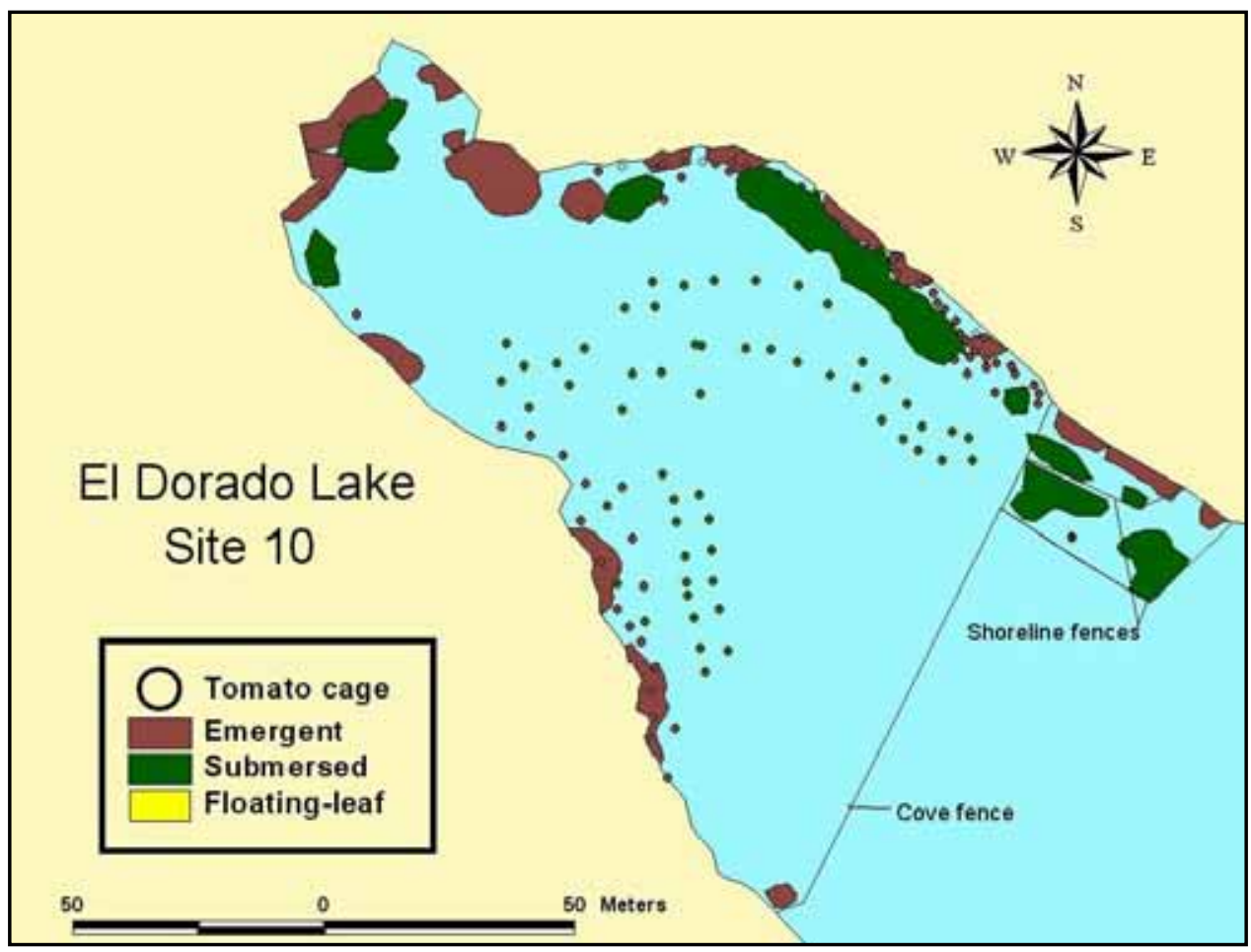

Figure 18. GPS map of Site 10, El Dorado Lake, October 1998

Southern naiad and Illinois pondweed were also found in several cages. American pondweed had spread extensively in shallow water $(50 \mathrm{~cm}$ deep and less) throughout the cove. Small (less than $1 \mathrm{~m}$ in diameter) colonies of water stargrass and southern naiad were also present. American pondweed and water stargrass had spread to fill approximately 50 percent of both shoreline fences constructed at this site. Sago pondweed, apparently growing from seed, was also observed growing behind the shallower shoreline fence. Illinois pondweed and wild celery did not appear to have survived low-water conditions in August. White water lilies were surviving, but evidence of grazing by turtles was observed and plants appeared to be weak. Spatterdock was not observed. All emergent species planted had survived, but most had not spread beyond tomato cages. One bulltongue colony at this site measured about $7 \mathrm{~m}$ in diameter. 


\section{Conclusions}

As stated earlier, the objectives of this project were to: (a) evaluate the suitability of several emergent, floating-leaved, and submersed aquatic species for establishment in the lake; (b) develop and test effective methods for establishing desirable aquatic plant species; and (c) establish founder colonies of aquatic plants in several areas of the lake. All objectives were met in this project.

Founder colonies were established at most sites in El Dorado Lake by the end of the second growing season. Nearly half the species of aquatic plants tested survived, grew, and spread successfully within protective exclosures, and some thrived without protection. Of 24 species tested (including southern naiad and muskgrass), 11 were deemed suitable for establishment in El Dorado Lake. The other species remain marginal candidates, and different establishment techniques may improve the chances that any of those could become established in this lake. At some sites, new colonies of some species were developing near the original transplants, exhibiting the early stages of founder colony spread. These colonies not only withstood low-water conditions, but also were able to spread in the presence of grazers. Some species were not exhibiting spread beyond protective areas, but colonies had survived low-water conditions and intermittent periods of grazing (following breaches in cages).

Although several difficult challenges were encountered, these were overcome to produce established native aquatic plant founder colonies at several sites. Protection from herbivores, primarily common carp, was the most critical need in establishing plant colonies during this project. In nearly every case, and regardless of species, plants in protective exclosures survived transplanting and began to grow. When protective exclosures were breached by common carp or turtles, nearly all plant (species) colonies exhibited declines. In addition to identifying the need to protect plants in this (or similar) project(s), the results of this project also make clear the need to maintain protective exclosures over the long term.

Cove fences proved to be inefficient at protecting submersed species in El Dorado Lake, mostly due to continual breaches in the fences by floating debris and beavers, which allowed entry by common carp and turtles. Additionally, high-water levels during the winter and spring periodically allowed carp into these areas. Once inside a cove fence, carp were difficult to remove. Pens and shoreline fences proved much more reliable in protecting plants, with only highwater conditions or damage from floating debris leading to access by grazers. Beavers seemed to leave these exclosures alone, perhaps because they did not interfere with the animals' activities: food supplies (trees) were often located in 
the backs of coves, behind the cove fences. Small-scale exclosures (tomato cages and orange cages) exhibited the greatest successes in protecting plants relative to all exclosures used in the study. However, these in themselves may have limited establishment and spread of plants because of the effects of constant abrasion against the mesh of the cage. A combination of small-scale and large-scale exclosures (tomato cages inside of pens or shoreline fences) appear to be the most effective means of establishing submersed and floating-leaved colonies in El Dorado Lake. Small-scale exclosures alone appeared to be adequate in establishment of emergent species.

Fluctuating water levels proved to be less a problem than initially expected in this project, except that it occasionally served as a means for herbivores to enter otherwise protected areas (swimming over fences during periods of extremely high water). Most plant species were able to survive low-water conditions that occurred during the second year. In fact, of all species tested, only four (wild celery, Illinois pondweed, elodea, and spatterdock) appeared to suffer extensively from desiccation. Moreover, of these four, only elodea was not found at all in the lake following low-water conditions, whereas the other three were recovering at some sites.

Turbidity may have played a role in survival of submersed species at some of the deeper sites. During both years, pens installed at the most turbid sites (more open areas) exhibited the poorest establishment, and expansion of colonies lagged behind pens in more protected, clearer waters. Although pen installation depth differences between these sites may also be relevant, these differences were less than $25 \mathrm{~cm}$ in most cases, and it is more likely that poor light penetration reduced growth rates of transplants in more turbid waters, overall reducing transplant success and subsequent growth. Turbidity did not appear to influence establishment of floating-leaved or emergent species.

Wave action may have caused some problems in establishing plants. The failure of American lotus to establish from $10 \mathrm{~cm}$ (4 in.) potted plants is believed to have been caused by damage to leaves and stems as waves pushed them against the abrasive cage materials. Similar damage to other species, most notably American pondweed and water stargrass, was noted in smaller cages. One means of eliminating or reducing this problem was construction of largerdiameter tomato cages, reducing the probability that portions of the colony were at risk to such abrasive damage.

Overall, plant establishment techniques applied in this project have succeeded in establishing founder colonies in El Dorado Lake. These founder colonies can be sustained over time by maintaining protective exclosures and removing herbivores when breaches occur. As long as these founder colonies are well maintained, they will be able to exploit conditions for spread and natural establishment in other areas of the lake should occur. 


\section{References}

Barko, J. W., Hardin, D. G., and Matthews, M. S. (1982). "Growth and morphology of submersed freshwater macrophytes in relation to light and temperature," Can. J. Bot. 60, 877-887.

Carter, V., and Rybicki, N. B. (1985). "The effects of grazers and light penetration on the survival of Vallisneria americana Michx in the tidal Potomac River, Maryland,” Aquatic Botany 23, 197-213.

Dibble, E. D., Killgore, K. J., and Harrell, S. L. (1996). “Assessment of fish-plant interactions.” Multidimensional approaches to reservoir fisheries management. L. E. Miranda and D. R. DeVries, eds., Amer. Fish. Soc. Symp. 16, 347-356.

Dick, G. O., Smart, R. M., and Keiser, E. D. (1995). “Turtles and their potential impact on aquatic plants in Guntersville Reservoir, Alabama,” Guntersville Joint Agency Project, Tennessee Valley Authority, Technical Report.

Doyle, R. D., Smart, R. M., Guest, C., and Bickell, K. (1997). "Establishment of native aquatic plants for fish habitat: Test plantings in two north Texas reservoirs," Lake and Reserv. Manage. 13, 259-269.

James, W. E., and Barko, J. W. (1990). "Macrophyte influences on the zonation of sediment accretion and composition in a north-temperate reservoir," Arch Hydrobiol. 120, 129-142.

. (1995). "Effects of submersed macrophytes on sediment resuspension in Marsh Lake, Minnesota.” Proceedings, $29^{\text {th }}$ annual meeting, Aquatic Plant Control Research Program. Miscellaneous Paper A-95-3, U.S. Army Engineer Waterways Experiment Station, Vicksburg, MS.

Nichols, S. A. (1992). "Depth, substrate, and turbidity relationship of some Wisconsin lake plants,” Trans. Wisc. Acad. Sci. Arts Lett. 80, 97-118.

Smart, R. M., and Dick, G. O. (1999). "Propagation and establishment of aquatic plants: A handbook for ecosystem restoration projects,” Technical Report A-99-4, U.S. Army Engineer Research and Development Center, Vicksburg, MS. 
Smart, R. M., Barko, J. W., and McFarland, D. G. (1994). “Competition between Hydrilla verticillata and Vallisneria americana under different environmental conditions,” Technical Report A-94-1. U.S. Army Engineer Waterways Experiment Station, Vicksburg, MS.

Smart, R. M., Doyle, R. D., Madsen, J. M., and Dick, G. O. (1996). "Establishing native submersed aquatic plant communities for fish habitat.” L. E. Miranda and D. R. DeVries, eds., Amer. Fish. Soc. Symp. 16, 347-356. 


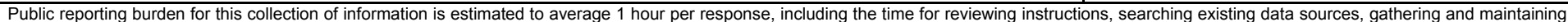

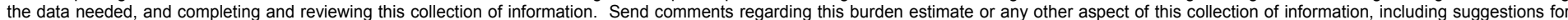

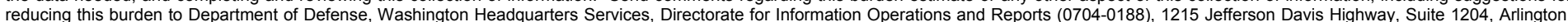

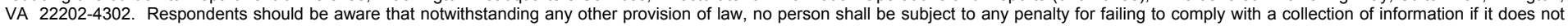
display a currently valid OMB control number. PLEASE DO NOT RETURN YOUR FORM TO THE ABOVE ADDRESS.

\begin{tabular}{l|c}
$\begin{array}{l}\text { 1. REPORT DATE (DD-MM-YYYY) } \\
\text { May } 2004\end{array}$ & $\begin{array}{c}\text { 2. REPORT TYPE } \\
\text { Final report }\end{array}$ \\
\hline
\end{tabular}

\section{TITLE AND SUBTITLE}

Aquatic Vegetation Restoration in El Dorado Lake, Kansas: A Case Study

3. DATES COVERED (From - To)

5a. CONTRACT NUMBER

96X3122

5b. GRANT NUMBER

5c. PROGRAM ELEMENT NUMBER

\section{AUTHOR(S)}

Gary Owen Dick, R. Michael Smart 5d. PROJECT NUMBER

5e. TASK NUMBER

5f. WORK UNIT NUMBER

33084

8. PERFORMING ORGANIZATION REPORT NUMBER

ERDC/EL TR-04-6

U.S. Army Engineer Research and Development Center Lewisville Aquatic Ecosystem Research Facility

201 E. Jones Street

Lewisville, TX 75057

\section{SPONSORING / MONITORING AGENCY NAME(S) AND ADDRESS(ES)}

Aquatic Plant Control Research Program

Headquarters, U.S. Army Corps of Engineers

Washington, DC 20314-1000

10. SPONSOR/MONITOR'S ACRONYM(S)

11. SPONSOR/MONITOR'S REPORT NUMBER(S)

\section{DISTRIBUTION / AVAILABILITY STATEMENT}

Approved for public release; distribution is unlimited.

\section{SUPPLEMENTARY NOTES}

\section{ABSTRACT}

The overall objective of the project was to begin restoration of spawning and nursery fishery habitat for the sunfish family (largemouth bass, crappie, and bluegill) lost from flood control operations (seasonal drawdowns) in El Dorado Lake, Kansas. When initially impounded, flooded terrestrial structure provided good habitat for the sunfish fishery. As flood control operations were implemented, habitat structure (primarily flooded trees and brush) degraded, leaving the lake poorly suited for this fishery. The loss of structure also contributed to increases in turbidity, further affecting the sunfish fishery.

Specific objectives of the project were to: (a) evaluate the suitability of several emergent, floating-leaved, and submersed aquatic plant species for establishment in the lake; (b) develop and test effective methods for establishing desirable aquatic plant species; and (c) establish founder colonies of aquatic plants in several areas of the lake. In addition to providing immediate nursery habitat for juvenile fish, these founder colonies were expected to provide propagules for natural spread to other areas of the lake.

\section{SUBJECT TERMS}

Aquatic vegetation

El Dorado Lake

Aquatic plants

Founder colonies

16. SECURITY CLASSIFICATION OF:

a. REPORT

UNCLASSIFIED

b. ABSTRACT
UNCLASSIFIED

c. THIS PAGE

UNCLASSIFIED

\section{Restoration}

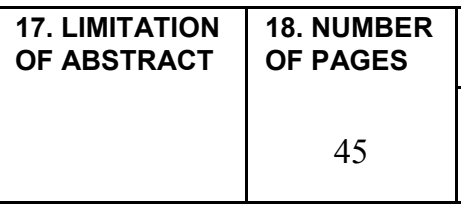

19a. NAME OF RESPONSIBLE PERSON

19b. TELEPHONE NUMBER (include area code) 